\title{
La persecución religiosa y la orden de San Agustín en la Independencia de Filipinas*
}

\section{LAS CORPORACIONES RELIGIOSAS}

En un folleto titulado: "Filipinas, problema fundamental», publicado por un español que oculta su nombre, pero al que se le nota haber residido muchos años en el Archipiélago, leemos lo siguiente: "Hemos dado el título de Problema Fundamental a este folleto porque el Archipiélago filipino necesita en estos momentos de una solución radical, patriótica y fecunda a todos los graves problemas que se ciernen sobre su cabeza.

Causa envidia y vergüenza, a la vez, el ver cómo Inglaterra en Hong-Kong, Singapore y Colombo, Holanda en Java, Francia en Tonkín han levantado en menos de veinte años ricas y populares ciudades, han fomentado el comercio, desarrollado en vastísima escala la agricultura y producido un río de oro para sus respectivas metrópolis, mientras nosotros, con mayores y más positivos elementos nos hemos cruzado de brazos y miramos en Filipinas como cosa baladí, en punto e intereses materiales, los más trascendentales problemas de su fomento y producción. Tenemos la agricultura rudimentaria o abandonada. De veintiséis millones de hectáreas de terreno cultivable sólo hay cultivadas dos o tres millones, y la mayor parte está cultivado por los frailes, que son los únicos que han hecho allí algo determinado y permanente. Los chinos corrompen el comercio y falsifican todas las in-

Véase estudio agustiniano, 7 (1972) pp. 71-103. 
dustrias, y la mayor parte de los frutos del país producidos con el sudor de indígenas son arrebatados por manos extranjeras. Los gobiernos sólo se han ocupado, de veinticinco años a esta parte, en llevar al Archipiélago organismos y reformas insensatas, fomentando así el partido llamado progresista, que no es ni más ni menos que el partido filibustero, que el día acaso no lejano, que salga del estado de crisálida, nos dará terribles mordeduras y pondrá en peligro el Archipiélago.

Hemos vivido muchos años la vida pacífica y tranquila de aquellos pueblos y de aquellas codiciadas posesiones nuestras, y tememos que el día menos pensado saan víctimas de extraños desafueros o de una perturbación sangrienta" ".

Esto fue escrito por un español residente en Filipinas, el año ı89.. Cinco años más tarde sus palabras tuvieron cabal y fatal cumplimiento. La insurrección filipina dio al traste con la labor de varios siglos, y Filipinas, el rico Archipiélago de S. Lázaro, conquistado por Legazpi y Urdaneta en el lejano I565, dejó de pertenecer a España. ¿Cómo pudo ocurrir tamaño desastre? ¿Cuáles fueron las causas y cuáles los efectos? ¿Quién o quiénes fueron los culpables? ¿Cómo se comportaron los españoles tanto los residentes en la metrópoli, como los del Archipiélago, durante la insurrección?

Aspectos parciales pero importantes de estos interrogantes, quedan aclarados en el presente estudio, para lo cual nos hemos valido principalmente de documentos de primera mano, como son los que la Orden de San Agustín posee en el Archivo del Colegio Seminario de PP. Agustinos-Filipinos de Valladolid, y recogiendo también cuanto se ha escrito sobre el particular, de un modo especial en autores españoles.

Pero antes de entrar en materia, creemos oportuno hacer un recuento de lo que España ha sido y significado en Filipinas y la labor desarrollada allá por las corporaciones religiosas, especialmente por la Orden de San Agustín, que fue la primera en llegar, la primera siempre en la brecha y la última en retirarse del campo de batalla, no sin dejar las vidas de muchos de sus hijos.

A este propósito estará bien recordar lo que un escritor ha dicho

1. Filipinas, problema fundamental, por un español (Madrid, 1891) (ARCHIVo AGUSTINOS-FIIIPINOS, $\mathrm{n} .^{\circ} 3995$, Valladolid). 
sobre el particular. "Entre las conquistas y descubrimientos de pueblos ignotos de que puedan gloriarse genéricamente los 456 millones de individuos que constituyen la raza blanca o caucásica - ha escrito Manuel Sastrón - no se ha logrado una de las primeras ni efectuado uno solo de los segundos por modo más conforme con la moral cristiana que aquel que se evidencia en el descubrimiento, conquista y régimen constituido por los españoles en el Archipiélago') ".

Sastrón nos señala, en síntesis, la labor efectuada por España en Filipinas desde los días de Urdaneta hasta los catastróficos de la revolución.

España instauró - $\mathrm{y}$ sin solución de continuidad ha seguido en Filipinas-, desde el mando de Legazpi, un sencillísimo régimen político, concordando con todas las medidas de gobierno que a la llegada de los españoles allí se conservaba: el respeto de los caudillos o caciques, a los jefes de familia y a los ancianos.

España destruyó en el Archipiélago filipino todas las tiranías de los «datos» y principales jefes de tribu y cimentó el nuevo organismo político administrativo sobre la base tradicional de que el indio viviese sobre la tutela de sus jefes y hombres principales.

España llevó a Filipinas en toda su extensión, sin limitaciones de raza, ni de tiempo ni de distancia, todo cuanto revela su progreso señalado en el régimen político de la metrópoli.

La dominación española acabó con la pirateria y con todas las guerras intestinas, creando luego la propiedad territorial, que entregó al indio que simplemente ofrecía labrar la tierra, en cuya plena posesión le ha garantizado siempre con toda la fuerza de la Ley Hipotecaria que regía en la Península.

Supo ordenar el reclutamiento del ejército indígena; la tributación comparada; los aprovechamientos forestales; la contribución industrial y comercial y urbana; los presupuestos.... sin abrigar nunca el menor propósito de explotación y de obtener el máximo provecho material, salvo contadas excepciones.

Pero hizo más la dominación española en Filipinas: sin tener en

2. M. SASTRON, La insurrección en Filipinas y guerra hispanoamericana en el Archipiélago, (Madrid 1.897), I, 9. 
cuenta para nada, ni nunca, preeminencias de raza y clase social, cuidó con atención digna de alabanza y elogio la situación pública.

No existía capital o cabeza de provincia en el Archipiélago en que no se hallara instalado algún establecimiento oficial o de enseñanza privada, habilitado para cursar y aprobar en él los primeros años académicos de segunda enseñanza, o algún instituto en donde se pudiera obtener completa, y aún con los estudios de aplicación, como entonces se decía.

Espãã̃a, que organizó la Iglesia en Filipinas en diócesis, dotó a cada una de ellas de un Seminario conciliar; además, en el ramo civil un cuerpo de médicos, titulares y forenses, lo mismo que, por lo que mi. ra a Sanidad, otros centros directivos y cuantos establecimientos, juntas consultivas provinciales, locales y delegados facultativos eran necesarios para cumplir tan altos deberes de humanidad.

En lo que a beneficencia atañe, los españoles en Filipinas cuidaron de fundar aquellos centros benéficos heredados de la caridad de Santo Tomás de Villanueva, San Juan de Dios y San Vicente de Paúl. Influidos los españoles -escribe el cronista- por esta santa atmósfera y conforme con la vertiginosa marcha seguida en la metrópoli, a poco de fundarse por el ínclito Miguel López de Legazpi, la ciudad de Manila ${ }^{3}$, sucesivamente, y con el producto de legados, donaciones y fundaciones, fueron creándose los establecimientos e instituciones de piadosos auxilios que para los menesterosos procuraba la beneficencia particular, y al propio tiempo inició la Beneficencia general los que a ella competen exclusivamente con las dotaciones del Estado, resultando que muy pronto se lograra en la capital del Archipiélago, como después en las cabeceras de provincias principales, casas benéficas destinadas al socorro de tanto desvalido como en el orden intelectual, moral y físico presentaban y siempre ofrecen aquellos pueblos de clima tan enervador y de hábitos muy distanciados de los preceptos más elementales de higiene privada y pública) ".

Los insurrectos de Filipinas y los cabecillas de la independencia

3. Dicha ciudad fue fundada por el noble conquistador en compañía de los agustinos que echaron los cimientos del convento de San Pablo en la misma fecha, el año 1571. (M. MERINo, Historia de la Provincia del Stmo N. de Jesús de Filipinos. En "Archivo Agustiniano. (1964).

4. M. SASTRON, o. c. I, 27-30. 
de aquel país trataron de justificar su actitud ante el mundo lanzando fuertes invectivas contra los españoles y argumentando, entre otros absurdos, que antes de arribar Urdaneta y Legazpi al Archipiélago, los filipinos constituían un pueblo altamente civilizado.

Esto hoy no puede admitirse. Como nos diría Barrantes, en « $E l$ teatro Tagalo", pierden el tiempo los que buscan en las historias de Filipinas datos que demuestren la potencia intelectual de la raza tagala. Y algo más se puede asegurar: que ni en el suelo, ni en la habitación, ni en el idioma ni en las prácticas religiosas hay un solo indicio que revele la existencia de una antigua civilización de alto nivel y propia de los pueblos filipinos ${ }^{5}$.

En el Archivo de PP. Filipinos de Valladolid, entre otros muchos documentos, hemos encontrado uno que se titula: "Conviene aclararlo». Es tan hermoso y elocuente, y viene tan a propósito para nuestro capítulo sobre las Corporaciones Religiosas en Filipinas, que no renunciamos a transcribirlo, al menos, en parte.

"No es sólo en el vestir - comienza diciendo el autor de esta apología inédita- donde la moda ejerce su soberanía, que también en las cosas más serias y trascendentales impone sus caprichos cuando los pueblos, al par que las personas, prefieren seguir la corriente de la frivolidad e investigar el porqué de los grandes acontecimientos. Tal vemos que sucede con el problema de la insurrección filipina). ${ }^{6}$.

«Aunque los gritos del combate que a diario se libra en uno y otro pueblo, en una y otra isla, de las llamadas Filipinas - sigue el autor- preocupa con harto motivo a todas las Cancillerías; aunque los políticos más sagaces se declaren impotentes para descifrar el enigma de la tenacidad filipina que a todos asombra, todavía la moda, la frívola y caprichosa coqueta hace decir a los españoles que tan profunda conmoción en un país tipo legendario de la paz octaviana, la produjeron los abusos de los frailes. ¿Es esto cierto? ¿Qué ha de ser? Pero lo quiere así la moda imperante y hay que dejarla hablar».

Así respondía, no ha mucho tiempo, un español sensato, que

5. "Los Frailes Filipinos". Por un español que ha residido en aquel país. Imp. Vda. de Minuesa de los Ríos, (Madrid 1898), 21.

6. "Conviene aclararlo". Manuscrito Anónimo conservado en el Archivo de Agustinos-Filipinos de Valladolid, núm. 4174, 1. 
había visto nacer la insurrección filipina, a las observaciones que hacíamos sobre lo necio de tamaña aseveración.

«Es cierto, proseguía, que en corrillos y plazas, en la prensa de cirrta calaña y hasta en el seno de las familias se da por demostrado que los frailes y sólo los frailes fueron la causa de que España perdiera sus colonias...».

El autor conocedor a fondo de la verdad y con deseos de enseñarla a los hombres imparciales y de buena voluntad se detiene luego analizando prolijamente la labor bienhechora llevada a cabo por las Congregaciones Religiosas en Filipinas.

No le vamos a seguir sus pasos; y hasta queremos evitar el tono apologético que sigue. Pero sí señalar los puntos centrales de su estudio.

Examina la acusación que se hacía a los frailes que reunían en sus manos las riquezas de todo el país, demostrando que todas las Haciendas que los frailes dichos poseían, no producirían por bien que s z vendieran "arriba de diez millones"; además de que su posesión era legal y legítima y datando su adquisición de siglos anteriores.

Demuestra más adelante que en general gozaban de mejor bien. estar y era éste más duradero en las familias aquellos colonos que cultivaban las tierras de la Iglesia, arrendadas a los frailes, que los mismos propietarios indios, los cuales vivían muchas veces en la miseria por inoperantes e inactivos.

Los primeros aprendían el ahorro de los religiosos y la previsión para el futuro; los segundos, derrochaban en pocos días el producto de sus fincas, acabando por hipotecarlas y malvenderlas para pago de acreedores.

Desciende luego a detalles examinando las fincas que poseían los religiosos en las provincias de la isla de Luzón, la más importante de Filipinas. Eran éstas Cavite, La Laguna, Manila y Bulacán.

En Bisayas, excepción hecha de Cebú, no poseían haciendas los religiosos.

Saca entonces la conclusión de que, insurreccionadas todas las Islas, maldiciendo en todas ellas del nombre español, no es posible que los motivos sean precisamente porque en (cinco provincias) tengan alguna hacienda sus antiguos y queridos maestros. 
Del mismo modo va analizando las distintas acusaciones aue se hacen a las Ordenes religiosas en el país: la intolerancia y la presión que ejercían sobre los pueblos cuyas parroquias suministraban. $\mathrm{Si}$ todos sabían que en el Archipiélago solamente se practicaba la religión católica, ¿en qué, pues, ni con quiénes habían de ser intransigentes o intolerantes?

$\mathrm{Y}$ es curioso observar con el autor cómo, si no eran intransigentes con los protestantes europeos porque apenas existían, ni tampoco con los naturales porque eran católicos, ni con la minoría china re. fractaria a toda religión que no fuera la suya, no cabía más que lo fueran con los españoles de Filipinas. "Buenos estaban en su mayor parte estos españoles "-dice socarronamente- para que los frailes se atrevieran a mirarles torcido... El que menos, se creía un sultán con todas las prerrogativas que el tal nombre lleva consigo)" ".

Otro autor español, residente por mucho tiempo en Filipinas, escribe unas breves páginas bajo el título "Los frailes Filipinos), abundando en los mismos argumentos. $\mathrm{E} 1 \mathrm{mismo}$ reconoce que se ha escrito tanto de los frailes, en pro y en contra, que si alguien recopilara lo principal, podría formar una abundante e interesante biblioteca. Como si las palabras (Filipinas) y (frailes) fueran inseparables.

En un juicio sereno y equilibrado reconoce que "hablar de los frailes por lo que hayan podido impresionarnos ocho o diez de ellos nos parece un error imperdonable. Pero menos puede perdonarse aún a los que juzgan de las corporaciones religiosas sin conocer a fondo su historia, sin apreciar sus hechos en conjunto, sin mirar desde la debida altura la obra civilizadora que en Filipinas han realizado ${ }^{8}$ Por lo que se refiere a Filipinas, lcs frailes españoles fueron allá directa y expresamente para convertir a sus habitantes, conservarlos en la fe católica y en la moral cristiana. Su misión era, pues, esencial y primordialmente religiosa y no cabe pensar que pretendieran ocupar cargos de gobernadores, militares, jueces o agentes de policía.

La calificación de reaccionarios, oscurantistas y retrógrados que se les atribuía dio margen a que el clero secular no se opusiera abiertamente a ciertas reformas, juzgando inútil toda resistencia. No se les

7. "Conviene aclararlo", 1. c. 6-10

8. "Los frailes filipinos". Por un español que ha residido en aquel país, (Madrid 1898), 5 
hubiera hecho caso entonces, y como buenos españoles y fieles súbditos, prefirieron callar oficialmente, aunque en la práctica hicieron cuanto pudieron por evitar los malos efectos de esas reformas.

$\mathrm{Y}$ ante el grave problema de la insurrección, ¿cumplieron los frailes en Filipinas con su misión y condición de españoles? el anónimo autor del folleto antes citado es expeditivo en la respuesta: "Sí; porque avisaron del peligro». Y explica: "En el púlpito, en la prensa, en las conversaciones, ante las autoridades todas, han denunciado los peligros de la masonería, el incremento que ésta tomaba, su carácter filibustero, la propaganda de libros antirreligiosos y separatistas, la existencia de colectas y cuotas para esos fines, cuantas noticias tenían de esto» "Puede convencernos la tesis del autor anónimo? La verdad es que sólo a medias. Si los frailes avisaron del peligro, como más adelante estudiaremos con documentos de primera mano, no les eximimos de culpa ante el desastre colonial.

A raíz de algunas reformas - no muy acertadas por cierto- llevadas a cabo en Filipinas como fruto de nuestras experiencias en las Cortes de Cádiz en I8 12 , Tomás Comyn dijo lo siguiente: "No es dable que pueda haber institución humana a un tiempo tan sencilla y firmemente fundada y de que tantas ventajas pudiera sacarse para el Estado como la que se admira, con razón puesta en planta, en los ministerios de estas Islas. $\mathrm{Y}$ es por lo mismo fatalidad bien extraña que, consistiendo en el sabio uso de tan poderoso instrumento el secreto, el verdadero arte de gobernar una colonia que se diferencia cual Filipinas de todas las demás, se ha dejado alucinar la superioridad, $\mathrm{d}$ z algunos años a esta parte, a punto de empeñarse en la destrucción de una obra que tanto conviene sustentary ${ }^{10}$. A este respecto es muy expresivo y por demás elocuente lo que decía en 1765 un Virrey de Méjico al rey Carlos III : "En cada fraile que pise el suelo filipino, tiene V. M. un capitán general y un ejércitos " ${ }^{11}$.

Aun en el aspecto político fue, en ocasiones, razonable la intervención de los religiosos, pues servían de intermediarios e intérpretes entre la autoridad oficial española y los (gobernadorcillos) locales. "La intervención oficial del fraile en los principales asuntos de

9. Ib. 17-18.

10. Citado el. "Los frailes filipinos", 39.

11. Ibid. 42 
la población - leemos en el citado folleto -es un derecho, algo cercenado en la actualidad, que viene vinculándose desde la conquista, y ello, aparte otras razones, porque suele ser el religioso el único español peninsular que hay en el pueblo. Este español es todo patriotismo, todo amor a los indígenas, a los cuales se halla unido con el noble lazo de la religión y del idioma: ¿Quién, pues con mayores tîtulos para representar dignamente al gobierno de España, interviniendo en los principales asuntos cualquiera que sea la clase de éstos, que atañen al pueblo?...)

Para comprender este párrafo y similares hemos de situarnos a finales del pasado siglo y en territorio fiilipino. Es decir, por un lado, la rica colonia del Archipiélago que se nos iba de las manos y por el otro, el fraile español, uno de los pocos hombres capaces, por su cultura, religión, patriotismo y amor desinteresado a España y a Filipinas de sostenerla y de conservarla para la metrópoli.

¿Cuál era la opinión del pueblo frente a los religiosos? Oigamos una vez más a nuestro autor anónimo. "Los filipinos que profesan verdadero amor a España, dice, los que abortan toda tentativa de desorden, son adictos lealísimos de los regulares, por lo mismo que ven que constituyen éstos un organismo genuinamente patriótico, de paz y de racional progreso. Con todo el capítulo de cargos contra los frailes españoles residentes en Filipinas, días antes de la insurrección, es tan extenso como infundado en muchos aspectos.

Se les acusaba de enemigos del Progreso. Podemos contestar con el duque de Allencon: "Se acusa a los frailes de retrasar el progreso de la colonia, de cohibir la tendencia de los pueblos hacia una vida más activa y más fecunda en esferas más anchas. Esto es altamente injusto. Los frailes han elevado al pueblo filipino al más subido punto de civilización de que es susceptible una raza que hace cuatro siglos se hallaba en la más espantosa barbarie. El tiempo y el contacto con los europeos hacía lo demás. Pero las órdenes religiosas pueden hoy mostrar con orgullo el resultado de sus esfuerzos en esos cuatros millones y medio de indígenas cristianos, en esos pueblos de Filipinas más civilizados, más independientes y más ricos que los de ninguna colonia europea en Asia ni aún en todo el Oriente»" ${ }^{12}$.

12. Ibid 56 . 
Con razón ha dicho también Barrantes: "No es la ilustración la mejor cifra ni el exclusivo atributo del hombre, sino las virtudes y las prendas morales que abundan no poco entre esos pobres indios. Por lo demás, cen qué colonia de las condiciones de las islas filipinas están los naturales del país tan instruidos como lo están los indios filipinos? ${ }^{13}$.

Es expresivo el dilema que plantean los autores apologéticos: "O los filipinos han progresado bastante, o no. Si lo primero, preciso es confesar quz se lo deben a los frailes; si lo segundo, si no han progresado y se creen todavía semisalvajes, ¿no les parece prematuro pedir diputados a Cortes y libertad de imprenta?" ".

Se les acusaba también de jugadores, borrachos y mujeriegos. No resistimos a copiar un párráfo picaresco y agudo que leemos en una apología inédita: "Si el fraile, llevado del buen humor nacido de la compañía de un compatriota, bebió un poco y estuvo alegre, ya cuenta que se embriagó; si vio a una mujer con un niño en el brazo que venía a hablar al cura de algún asunto de los infinitos que ocurren en el pueblo, ya dice que conoció a la querida y a un hijo del fraile; si se reunieron algunos curas de pueblos vecinos y se pusieron a jugar a la brisca o la treinta y una para matar el tiempo; ya refiere que armaron el juegos) ${ }^{15}$.

Jagor ha escrito sobre el particular párrafos que son tanto más importantes y meritorios, cuanto que el escritor alemán ataca por sistema sañudamente todo aquello que se relaciona con el catolicismo. "Es frecuente - dice Jagor- echar en cara a los frailes de Filipinas sus costumbres libres. Se dice que el convento está lleno de muchachas bonitas, entre las cuales el cura vive como un sultán en su serrallo.

13. Ibid. 57 .

14. Ibid. 59 .

Con ocasión del IV Centenario de Ia Provincia Agustiniana del Santísimo Nombre de Jesús de Filipinas, celebrado en 1965, los religioscs del Colegio de Valladolid publicaron ensayos y estudios en distintas revistas de la Orden extrañas a la misma poniendo de relieve la labor científica y cultural de los Agustinos en el Archipiélago. A ellos remitimos al lector, Véanse entre otras, las siguientes revistas: "Archivo Agustiniano", Valladolid, 1965-66; "Casiciaco", Valladolid número extraordinario dedicado a Filipinas: "Apostolado", varios números aparecidos a lo largo del año citado; "Analecta Agustiniana", "Mundo Hispánico", de Madrid, y otras de valor secundario.

15 Ibid. 68. 
Respecto de los sacerdotes indígenas, quizá haya algo de verdad; pero en los españoles ofenden en lo más mínimo la más rígida moral. La servidumbre estaba compuesta de hombres, y alguna vez, de dos o tres mujeres de avanzada edad) ${ }^{16}$.

No seamos, sin embargo demasiado cándidos en esto, y admitamos que pudieron darse y de hecho se dieron abusos. Sin embargo, no es justo ni razonable calumniar a todas las órdenes religiosas por los casos singulares que se dieron. Podríamos aplicar a los frailes lo que el intelectual y principal cabecilla de la insurrección filipina, José Rizal, decía de los filipinos en el periódico "La Solidaridad": "Que las faltas de unos pocos se atribuyan a toda la raza, no es cosa nueva para nosotros). Que los desaguisados de un fraile, las anomalías de otros sirvan para calumniar a toda la corporación, no es tampoco cosa nueva.

Por lo demás, son abundantes los testimonios de las primeras autoridades españolas en Filipinas en favor de las Ordenes religiosas. Podríamos aducir mucho, pero nos limitaremos a exhumar algunas de cierto relieve. D. Rafael María Aguilar, Capitán General y gobernador superior de Filipinas, dando cuenta al Rey de España con fecha 25 de Noviembre de 1804 sobre lo ocurrido con respecto a los curatos de Imus, Las Piñas y Santa Rosa, decía lo siguiente: "Testigo es la historia de que a los primeros religiosos que vinieron se debe la conversión de los infieles que había en estas islas; y para conservarlas siempre a devoción de $\mathrm{V}$. M. es preciso que se observe el mismo medio por el que pudo conseguirse el establecimiento de sus administraciones) ${ }^{17}$.

Tomás de Comyn, factor de la Compañía de Filipinas y eminente estadista, escribe en 1810: "De poco habrían servido el valor y constancia con que vencieron a estos naturales Legazpi y sus dignos compañeros, si no hubiera acudido a consolidar la empresa el celo apostólico de los misioneros. Estos fueron los verdaderos conquistadores, los que $\sin$ otras armas que sus virtudes, se atrajeron las voluntades, hicieron amar el nombre español, y dieron al rey, como por milagro, dos millones y más de vasallos sumisos y cristianos; estos fueron los legisladores de las hordas bárbaras que habitaban las islas de este inmenso

16. Ibid. 69 .

17. Ibid. apéndice n. 3,110 . 
archipiélago, realizando con su suave persuasión los prodigios alegóricos de Anfión y Orfeos ${ }^{18}$

Aduzcamos otros testimonios. En una "circular muy reservada" que dirigió a los alcaldes mayores y gobernadores de provincias al poco tiempo de hacerse cargo del mando supremo y de la Capitanía general de las Islas, Marcelino de Oráa escribía: "Los que han sido llamados por la soberana voluntad de Su Majestad para el gobierno de estos remotos países, no deben perder de vista los medios de que se valieron sus descubridores para adquirir a favor de la Corona de España esta porción considerable de territorio, con la obediencia y reconocimiento de sus numerosos habitantes, pues los mismos medios que se emplearon con tan feliz éxito para la conquista deben servir para su conservación y fomento. Estos medios no han sido otros que los de la persuasión y el ejemplo, la predicación de los dogmas de nuestra religión sacrosanta y de la sublime y pura moral del Evangelio que aquellos dignos españoles cuidaban de confirmar estrictamente con sus costumbres y su conducta ante los sencillos y pacíficos habitantes) ${ }^{19}$.

Patricio de la Escosura, Comisario Real en el Archipiélago, se expresaba del siguiente modo en 4 de mayo de 1863 : "Excuso, pues, insistir en que el Comisario Regio, penetrado y conocedor de la importancia de los servicios prestados aquí a la religión y al Estado por las órdenes religiosas, y persuadido además de que son hoy todavía, y lo han de ser por siglos, el instrumento más eficaz y poderoso de civilización y engrandecimiento..., las respeta y considera en lo que realmente valen, y lo que es más, cuenta con el auxilio de sus luces y la actividad de su nunca desmentido celo para llevar a cabo la importantísima comisión que le está confiadas) ${ }^{20}$.

D. José de la Gándara, en un informe que dirigió en 1869 â ministro de Ultramar, insertaba una interesante y bien documentada "Memoria», de la que extractamos el siguiente párrafo: "Las órdenes religiosas vinieron al Archipiélago con el descubrimiento y la posesión. Su historia es la historia de Filipinas; su influencia ha sido siempre absoluta y sigue siendo importantísima. No puede desconocerse que

18. TOMAS DE COMYN. "Estado de las Islas Filipinas en 1810" Edición con notas de D. José Felipe del Pan, anexo a la "Revista de Filipinas", (Manila 1877).

19. "Los frailes filipinos", Apéndice n. ${ }^{\circ} 6,118$.

20. Cit. por "Los frailes filipinos", Apéndice n. 7, 122. 
sus servicios en lo espiritual y temporal han sido para la reducción, la civilización y organización social de estas islas más eficaces y provechosos que todos los medios de la política de gobierno y de administración que aquí ha ejercido el poder supremo de la madre patria) ${ }^{21}$

En otra ocasión Domingo Moriones, Gobernador General de las Filipinas por el año I877, escribía al P. Provincial de los Agustinos, a la sazón M.R.P. Fr. José Corugedo, una interesante carta privada. A ella pertenece este párrafo: "Multitud de hechos que la historia registra demuestran los cuidados, afanes y sacrificios empleados aquí por las órdenes religiosas en el cumplimiento de su doble misión y tres siglos de tenaz y santa lucha, el éxito que representa la redención cívico-religiosa de seis millones de habitantes y la prosperidad debida a su patriótica influencia nos ofrecen una prueba irrefutable de lo que fueron en el pasado, lo que son en el presente, y lo que deben ser en el porvenirs ${ }^{22}$.

Finalmente, don Valeriano Weyler, Capitán General del Archipiélago en 1891, al tiempo de entregar su mando, dejó escrito otra importante alabanza a la obra de los regulares en Filipinas. "La misión de las órdenes religiosas — dejó escrito en su memoria- no ha terminado, como pretenden los que, mal avenidos con ellas, piden que desaparezcan, o por lo menos que se les vaya quitando influencia, en lo cual se han inspirado muchas de las reformas que durante cierta época se han dictado. No se tiene presente que hemos dominado en Luzón y en Bisayas por nuestra influencia moral, sostenida principalmente por el párroco que, por el dominio que ejerce con sus feligreses, sabe lo que ellos piensan, les aconseja, les dirige, les hace españoles, prestando poderoso auxilio a la autoridad para la recaudación y cumplimiento de todas las órdenes, $y$, finalmente, fiscalizando a los gobernadorcillos y demás municipios en los padrones y servicios de que están encargados) ${ }^{23}$.

No son menos elocuentes y sí mucho más importantes - por venir de quien vienen - los argumentos de hombres que hacían gala de ser antirreligiosos, anticatólicos o anticlericales.

Así el citado doctor John Bowring, ilustre, distisguido y severo

21. Ibid, Apéndice n. 8, 122-123

22. Ibid, Apéndice n. ${ }^{\circ} 9,127-128$

23. Ibid, Apéndice $\mathrm{n}^{\circ} 11,131-132$ 
protestante, después de una visita efectuada a las Islas Filipinas, confesaba: "He encontrado bastantes frailes objeto de especial respeto y afecto, y en realidad lo merecían, como guardianes y restauradores de la paz de las familias y como protectores de los niños en sus estudios, $y$, por otra parte, asociando sus esfuerzos al bienestar de sus respectivos pueblos" ${ }^{24}$.

El liberal Vera López, después de permanecer algunos años en Filipinas, escribía acerca de los Agustinos al tiempo de dedicarles un estudio sobre economía: "A vosotros sucesores de aquellos varones ilustres llamados Urdaneta, Herrera, Rada, Aguirre, Gamboa y tantos otros que tan altos pusieron sus esclarecidos nombres en la historia sin ejemplo del descubrimiento y posesión de esos ricos Archipiélagos: a vosotros os dedico este modesto trabajo. Fruto de catorce años de estudios económicos sociales sobre este país, llevados a cabo a impulsos únicamente del amor santo a la Patria, quiero identificarlo con los que, como yo, han sabido amar y amar ante todo y sobre todo, a nuestra madre común "España» ${ }^{25}$.

También ha salido el nombre de D. Patricio de la Escosura. Ahora volvemos sobre este predilecto discípulo de Alberto Lista y de Lacroix, el político que estuvo desterrado en Olvera, el progresista de I 85, porque, al tiempo de volver a las Filipinas, declaraba en las Cortes en plena desunión política: "Y vuelvo a Filipinas : las comunidades religiosas me recibieron con una preocupación natural, dados mis antecedentes, y en la primera entrevista estuvimos recelosos, unos de otros, $y$, sin embargo, yo voy a decir ahora que si presumo haber dejado amigos en Filipinas, es precisamente en las comunidades religiosas. En un país casi despoblado, con escasos medios de comunicación marítima, ¿quiénes, sino aquellos hombres que pueden hablar en nombre de Dios serían capaces de hacer que los indios adoren el nombre de Castilla, como adoran el nombre de Dios?” ${ }^{26}$.

Un ilustre militar norteamericano exaltaba asimismo la labor realizada por las Corporaciones religiosas en Filipinas. "Los españoles - decía - han hecho por las Filipinas más que cualquiera otra nación

24. Ibid. 36

25. Citado por Manuel Sastrón: "La insurrección én Filipinas, XI, 201

26. Ibid. 201. 
colonizadora por un pueblo oriental. España les dió sus principios, su rzligión, su idioma y su cultura, no superficialmente, sino penetrando en el alma de los indígenas. No obstante ser los filipinos malayos, nada tiene de común con los malayos. En lugar de la verdadera barbarie, el canibalismo y la idolatría, España implantó el catolicismo, que ahora profesan las nueve décimas partes de la población, y elevó la condición social de la mujer, que no es casi una esclava, como en otros países orientales, sino la señora de su hogar. La labor realizada en tres siglos por los religiosos españoles es admirable y no puede dejar de excitar nuestro aplauso, y a pesar de las muchas dificultades con que tropezaban, España continuaba su obra de cristianización cuando la hicimos la guerra... Nuestro pueblo no puede apreciar en toda su extensión la deuda, que hemos contraído con España) ${ }^{27}$. Las palabras del general Leonard Wool serán corroboradas por la de otro hombre ilustre, el Dr. D. Julio Didiot: “innegable e inmensos -escribía Didiot- son los servicios que han prestado las Ordenes Religiosas a la sociedad y a la Iglesia. Obra suya ha sido en gran parte la civilización europea: por muchos siglos han sido esos hombres los únicos educadores, los únicos agricultores y los únicos letrados)s ${ }^{28}$.

¿Qué decir, como final de este capítulo, de los propios filipinos? Pues que siempre fueron respetados los religiosos por los naturales. "La mortificación, la austeridad, la santidad de vida, el desinterés y la abnegación que distinguen al religioso del viajero, del comerciante y del conquistador no ha pasado nunca desapercibidas hasta de los más rudos salvajes. La resignación evangélica para sufrir y padecer trabajos, incomodidades, desprecios y malos tratos por servir a sus semejantes, les ha enaltecido a los ojos de la humanidad, haciéndoles objeto de una veneración profunda y sincera ${ }^{29}$.

Terminamos con el testimonio del conocido periodista, Estrada, el cual en 1885 escribía: "Filipinas es la primera colonia del mundo gracias a los frailes, envidia y asombro de las naciones extranjeras que la juzgan mejor y tienen en más aprecio que nosotros mismos. Defen-

27. Artículo publicado en el "Boston Transcript" y traducido y trans" crito por "El Imparcial", Manīia, diciembre, 1905.

28. "El Imparcial", Manila, diciembre, 1905.

29. E. Zamora, "Las Corporaciones Religiosas en Filipinas". (Valladolid, 1901), 404. 
der hoy a los frailes es defender una causa nacionals ${ }^{30}$. Y el de D. Juan Caro y Mora: «El fraile nace en la Península y muere en la colonia por la cual se le educó; siente el nombre de España con todos los entusiasmos y puros recuerdos de la edad juvenil y se interesa por Filipinas como se interesa por la vida misma. Su existencia, consagrada a Dios y a la Patria, es una jornada hecha entre los confines de la tierra ; hecha como entre los crepúsculos de un lârgo día ${ }^{31}$.

30. Ibid., 442.

31. Ibid., 447-8. 


\section{EL PROCESO DE EMANCIPACION}

a.- Las causas

De antemano sabemos que la mayor parte de las cosas que aquí vamos a decir son ya conocidas de los estudiosos y se han dicho ya por los historiadores contemporáneos. Sin embargo, nos ha parecido conveniente y casi necesario recordarlas de nuevo, sobre todo, los hechos básicos y fundamentales del proceso de emancipación de Filipinas para, de este modo, ponderar más adelante en su justo valor la persecución religiosa.

Pues bien; "la formidable conjura que entre tagalos se urdiera contra la dominación española - ha escrito Sastrón- queda a nuestro modesto juicio explicada. Resumiendo, habremos de afirmar y afirmamos no reconocer otras causas que el concepto de independencia explotado por la a todas luces injusta propaganda sostenida por las sociedades secretas, con forma extraña entre aquella raza, contra la dominación española...

La masonería filipina, fusionada con la (Liga filipina), formada por Rizal, y ésta fusionada, a su vez, con el “Katipunan» de Marcelo $\mathrm{H}$. del Pilar, puesto que no prosperaron otras organizaciones de triángulos propuestos, he aquí cuanto en nuestro sentir constituye el triste proceso de la revolución en Filipinas» ${ }^{1}$.

Un modo harto simple, como se ve, de enfocar el problema de las causas que motivaron la insurrección filipina de 1896 . Nuestro deseo es examinar más detenidamente el tema $y$, después de consultar la bibliografía y documentación oportunas, sacar la conclusión general de que aquellas fueron muchas y complejas, algunas de las cuales debidas incluso a los mismos españoles. El hecho de la revolución resulta, de este modo, más amplio y de mayor responsabilidad en unos y en otros. En cualquier caso, nuestras conclusiones no aspiran a remover el cuadro clásico sobre la cuestión.

¿Tenía que llegar aquel momento fatal para la historia de España? Parece que sí. Pero nosotros juzgamos ahora hechos humanos y los motivos que los produjeron. Vamos, pues, a estudiar con serenidad los factores que ocasionaron tan tremenda catástrofe. Al final veremos cómo, en el fondo, todo aquello era una repetición de los muchos re-

1. MANUEL SASTRON: "La insurrección en Filipinas" IV, 66. 
veses en que se había iniciado la historia de la Península en los albores del siglo XIX, cuando la emancipación de América.

"Yo no creo - escribe el autor de los Apuntes históricos- que haya historiadores medianamente familiarizados con las reglas más elementales de la crítica que aún atribuven nuestro desmoronamiento colonial a determinadas colectividades alli existentes. No creo que deba atribuirse aquella lucha a las corporaciones monásticas, a los abusos de la administración, a las reformas introducidas en el régimen de los municipios, ni aun a las sociedades masónicas tal cual se hallan condenadas por la Iglesia, ni a ningún otro factor aisladamente considerado. El conjunto de todos estos elementos, juntamente con la propensión innata a la reconquista de la libertad, habrán sido los productores necesarios de la revolución, la causa determinante del levantamiento contra el dominio de España. Se buscó un fin, y creyó preciso remover los obstáculos para conseguirlo y era lógico que se utilizasen las innovaciones y medios reformistas implantados por nuestros gobiernos en aquellas colonias.

La masonería cualquiera que fuese su carácter (y no nos fijamos en el nombre), necesitaba obrar, pero clandestinamente. Sus manejos se los impedían los religiosos, la Guardia Civil, el empleado de honradez y amante de la Patria, y por eso eran aborrecidos, como se aborrecen al que de algún modo coarta nuestras libertades y descubre nuestras intenciones' " .

El origen de la revolución filipina contra España ha sido tan embrollado - viene a decirnos Durán- y tan confundido por escritores interesados y ajenos de espíritu de imparcialidad que debe presidir a todo trabajo histórico, que hoy, después de lo mucho que se ha escrito por publicistas de aquende y allende los mares, apenas puede el que, con sensatez quiere juzgar el asunto, saber a qué atenerse respecto de la cuestión citada. No parece sino que los que han escrito sobre el asunto, salvo rarísima excepción, unos movidos por el espíritu de sec$\mathrm{ta}$, otros tal vez, por echar responsabilidades propias sobre personas inocentes e indefensas, se han movido llevados por un interés especial de condensar nieblas y oscuridades sobre un punto que resplandece con entera claridad ${ }^{3}$.

2. в. MARTINEZ, Apuntes..., XLVIII, 520 .

3. JOAQUIN DURAN: "Exisodios de la Revolución Filipina", 9. 
La verdad es que nosotros no lo vemos tan claro como el candoroso autor agustino. Es cierto que si un espíritu sereno y amante de la verdad analiza, sin apasionamientos ni preocupaciones de escuela, el origen y desarrollo del "Katipunan», en sus dos etapas del 96 en que estalló y del $9^{8}$ en que, después de dámosle como sepultado en la llamada "Paz de Biac-nabato, resucitó con más bríos y pujanzas, no tiene más remedio que confesar con nosotros que, entre las múltiples concausas secundarias que le dieron vida, destaca de una manera peculiar la acción funestísima de la masonería sobre indígenas cuya idiosincrasia especial abraza con gusto lo misterioso y persigue con entusiasmo toda ridiculez aparatosa.

Pero no es menos cierto que las causas fueron muchas y más complejas. Por lo que no se pueden reducir solamente a la acción, directa o solapada, de la masonería. En esto, creemos, que se han equivocado todos, o casi todos los autores que han tratado el asunto de la insurrección. Porque las causas obedecen, en primer lugar, a fenómenos de biología histórica, a la lucha de raza y ansia de independencia del tagalo, como más adelante hemos de ver.

En segundo lugar, la insurrección obedece a la época en que se produjo, siendo producto de la misma, cuando tenía el ejemplo cercano de Cuba, hasta el punto de que ambas insurrecciones y consiguientes guerras van unidas en un mismo capítulo de la historia de España y de Estados Unidos.

"Con la insurrección de Cuba - dice a este propósito el historiador español Aguado Bleye- vino a complicarse la de los tagalos y mestizos de la isla de Luzón, que se sublevaron en septiembre de 1896... La sublevación renació después del desastroso combate de los pobres y escasos barcos españoles con la escuadra norteamericana en la bahía de Manila»". Ya en capítulos anteriores hemos visto la acción decisiva de los Estados Unidos en los asuntos de Cuba y de las islas Filipinas; y en capítulos siguientes de nuestro estudio veremos cómo España mantendrá una guerra con esta poderosa nación; lo que aprovecharán los rebeldes tagalos para declararse independientes de la madre Patria.

Finalmente, en esta cuestión, cuentan mucho los desaciertos po-

4. P. AgUAdo BLEYE: "Manual de Historia de España". Espasa-Calpe; (Madrid 1956) III.; 778. 
líticos de los españoles al tiempo de poner remedio a los males de nuestras colonias, como hemos podido ver atrás cuando juzgamos la conducta de Cánovas, Maura, Silvela o Moret. Saturado entonces el indígena filipino de libertades que ambicionaba pero no comprendía del todo, comenzó a notar en su corazón un sentimiento que no dejaba de halagarle, aunque todavía no le entendiera bien espoleándole hacia la independencia. Rota ya la influencia moral que el párroco había ejercido sobre sus feligreses, la idea separatista salió desbordada, encarnando luego en revolución. Ahora es cuando iban a tener fatídico cumplimiento las palabras de Retana cuando dijo que cal filipino sagaz no se le oculta que a medida que el fraile se le ha ido achicando, el predominio nuestro viene a menos visiblemente». $Y$ las de aquel ilustre militar español cuando afirmó: "por cada fraile que el gobierno quite de Filipinas, tendrá que ser reemplazado por un centenar de bayonetas" " ${ }^{5}$.

José M. del Castillo y Jiménez, a propósito de los motivos que forjaron la insurrección de Filipinas, escribe: "Las cuestiones que afectan al feroz imperio filipino, brillantísima colonia española, miradas hasta el presente con un interés pasivo y secundario por los gobiernos responsables, han despertado la curiosidad de la opinión pública y se han puesto de moda, formando cada cual, en las más peregrinas fantasías de la mente, mil inapropiados juicios respecto a un pueblo que es desconocido por la mayoría - hasta por muchos de los ministros que desempeñaron la cartera de ultramar- forjando mil desatinadas cábalas en deducción de los motivos fundamentales de la insurrección; y aunque a mi juicio son diversos estos motivos, y todos ellos han contribuido por modo eficaz a traer esta abrumadora $y$ crítica situación el más esencial, porquie se condensan en él todos los motivos y todas las causas, es el abandono en que los gobiernos han mirado aquel pedazo de tierra española, regida por la voluntad o el capricho de las autoridades, pendiente de las genialidades de las unas y de las otras y en medio de la mayor ignorancia por parte de todos ${ }^{6}$.

De un lado, parece que fue el pueblo filipino el que, llevado del odio de raza, se echó en manos de las sectas masónicas para conseguir

5. RETANa: "Politica de España en Filipinas", año IV, n. 89.

6. JOSE M. DEL CASTILLO Y JIMENEZ: "El Katipunan, o el Filibusterismo en Filipinas"; (Madrid 1897) 3-4. 
por su medio la independencia nacional. De otro, estuvo el español, o mejor, las contemplaciones, tolerancias, confianzas y excesivas generosidades por parte de los gobernantes, los cuales no habían aprendido la lección que les dieron en revueltas anteriores, ni conocieron los impulsos del pueblo nativo.

Para conocer las causas de la insurrección del 1896 , no es necesario remontarse a los tristes sucesos del año 1872 que se desarrollaron en la provincia de Cavite, de la que saldría más tarde el general Aguinaldo, porque no guardan analogía alguna con los sucesos de la segunda insurrección, si bien pudieron ir preparando el camino a la misma; $y$, además, porque el general Izquierdo, con la energía propia de una autoridad española, supo castigar a los insurgentes de aquellos días de tal modo, que pronto se borrarán de la memoria, aunque en la historia se sellaran con la sangre generosa que vertieron los bravos pacificadores de la rebelión.

Pero ya es hora de que digamos que, efectivamente, si no única y exclusiva, una de las principales causas de la insurrección fue la masonería.

Porque asi funestas fueron aquellas leyes -escribe José $M$. del Castillo y Jiménez-, más funestas y desdichadas han sido, con oprobio para sus personas, ciertas inexpertas y poco escrupulosas entidades que vinieron a Filipinas a sembrar la ruina en las conciencias y el escándalo en la sociedad, iniciando a los indios y mestizos en logias masónicas, con una imprudencia que hemos de calificar de criminal, aunque se nos duda creer, por un exceso de benevolencia, que jamás pudieron tener intentos de carácter político. Uno de estos primeros propagandistas de la masonería indígena fue, allá por el año r888, el entonces gobernador civil de Manila, Sr. Centeno, de triste memoria en este país.

(El, en unión del vanidosillo Sr. Quiroga Ballesteros, Director civil por aquellos días, fue quien consiguió aquella manifestación contra el Sr. Arzobispo, que lo era el P. Payo, con motivo de la oposición que este prelado hizo al decreto del Sr. Quiroga, sobre prohibición de la entrada de los cadáveres en las iglesias.

"Âquella manifestación fue el grito de sedición que dieran los rebeldes de hoy protegidos por la sanción oficial y la representación insertante de estos dos sujetos; y esa sedición fue tomando cuerpo en 
el seno de las logias masónicas, denominadas algunas de ellas, Quiroga, Centeno y Morayta) ?

Efectivamente, hay que convenir en que la masonería fue la base de la mala semilla sembrada en Filipinas; y fue, además, el fundamento y la base de aquella otra sociedad secreta que se llamó "Katipunan», reflejo fiel e hija muy querida de la secta carbonaria ${ }^{8}$.

Las sectas masónicas se extendieron, sobre todo, por entre las gentes sencillas del campo, explotando su ignorancia, pues se las hizo ver que se trataba de fines humanitarios y filantrópicos, de auxilios mutuos, de reconcentración de fuerzas y de elementos valiosos que les ayudarian en sus necesidades pecunarias y que les sacarían de todos sus apuros.

$\mathrm{Y}$ como el sediento que busca fresco manantial, buscaron estos incautos en la masonería la redención de unas faltas que no cometieron. Los hábiles cabecillas habíanles predicado la asociación entre ellos; habíanles dicho que tenían que conquistar los puestos que los españoles desempeñaban en Filipinas; que todos, indios y españoles, tenían iguales derechos e iguales deberes; que los códigos no establecían diferencia alguna; que los frailes habían terminado su misión y su dominio espiritual; que el fraile era una perturbación en el hogar y en la familia; que el hombre es libre y como libre, dueño de sus actos y de sus voluntades, sin que pudiera permitir coacción de ningún género; que la administración pública española era detestable, porque los acosaban en tributos y con cargas que no debían satisfacer ni tolerar; $y$ así de esta suerte fueron despertándose al fanatismo de esas infames enseñanzas las conciencias deprimidas .

7. Ibid 11-12.

8. Hasta ochenta y seis fueron las logias que se llegaron a establecer en el Archipiélago, repartidas del siguiente modo: 25 logias en Manila y su provincia; 2 en Cavite; 3 en Bulacán; 9 en la Pampanga; 3 en Nueva Ecija; 1 en Mindoro; 2 en IMorong; 2 en Tayabas; 2 en Camarines; 2 en La Laguna; 1 en Las Islas Batanes; 1 en Layte; 1 en Bataan; 1 en Arti que; 1 en el Distrito de la Concepción (Ilo-Ilo) 5 en Batangas; 5 en Pangasinán; 3 en Tarlac; 2 en Ilo-Jlo; 3 en La Unión; 3 en Ilocos; 1 en Lápiz; 1 en Mindanao; 1 en Bohol; 1 en Masbaté; 1 en Cebú y 1 en Tamboanga. (Datos tomados en el citado libro de José $M$. del Castillo y confirmados por papeles y documentos que se conservan en el Archivo de PP. Agustinos-Filipinos de Valladolid, como se verán en el Apéndice de este estudio.

9. "El Katipunan", 10. 
Desde luego, la masonería ha sido el taller donde se ha fundido el odio a España y a los españoles. La masonería fue la que despertó sentimientos de ambición entre la raza de los mestizos de chino, la cual, con mayor capacidad en inteligencia, era inferior en sentimientos. Esta raza ha traído - escribe un autor- la prostitución a la familia indígena; ella que predica la libertad, practica a espaldas de la ley la inicua de la esclavitud; tiene a los indios por miserables esclavos.

Esto hay que verlo para creerlo porque el indio es así; tal vez por una corriente de simpatía se acerca, se confunde y se deja seducir por el mestizo de chino, y huye del español que le trata bien, le da buena alimentación, sanos consejos y estudios, civilizándole, dignificándole y engrandeciéndole ${ }^{10}$.

El odio de raza que es transmitido de generación en generación, y que ahora les ciega tanto que sólo ven con tintes rojos la raza blanca contra la cual han lanzado una sacrílega maldición, ha sido estimulado por las logias masónicas.

Uno de los principales propagandistas de la secta en el Archipiélago fue Faustino Villarruel, hasta el punto de que él mismo afirmaba haber fundado en su propia casa las logias de "Walana), "Luzón», "Modestia», "Dalisay" y "Taliba». Con meteórica rapidez, la masonería acumuló en Filipinas, no sólo los elementos campesinos, como hemos descrito arriba, sino y principalmente los elementos de más relativa capacidad intelectual entre los elementos indígenas.

La organización masónica filipina dependía del "Gran Oriente Español», el cual no solo toleró los propósitos separatistas y la lucha contra las corporaciones religiosas, sino que las alentó con su ayuda económica desde el propio corazón de España.

Don Manuel Sastrón quiere disculpar a los masones españoles diciendo que a buen seguro ignoraban los verdaderos fines de los masones filipinos; pero resulta poco exacta esta afirmación, al menos por lo que al Sr. Morata y otros principales se refiere. Los documentos y cartas que se conservan en el Archivo de Agustinos-Filipinos declaran todo lo contrario.

Los masones no ignoraban de qué suerte existía en su seno la

10. Ibid. 13-14. 
idea de la rebelión separatista y bien pudo el masonismo, que tales ideas defendía, trabajar tan activamente como lo hacía seguro del éxito. De tal forma que ya desde 1892 decir (filibustero) era lo mismo que decir "masón"; pues ya en este mismo año se pudo afirmar en notables documentos de valor oficial literalmente lo siguiente: "No hay un solo de los jefes y organizadores de las asociaciones filibusteras que no sea masón" ".

Ahora tendríamos que hablar de la llamada "Liga Filipina" organización revolucionaria verdaderamente avasalladora. Sastrón nos la describe y explica al detalle. Se trataba de un comité de propaganda, esencialmente revolucionario, que tenía a su cargo el distribuir los escritos y folletos de carácter separatista. Se había creado éste en la ciudad de Manila y lo dirigía un astuto mestizo, Doroteo Cortés, figura antipática y que había hecho fortuna dejando a otros en la miseria. Los escritos se difundían entre la masa indigena que dócilmente pagaba por ellos más de lo que valían. Con el dinero recaudado se cubrían los gastos de los indios filipinos que se habían trasladado a España y otros puntos de Europa con fines de propaganda subversiva.

Entre los favorecidos con este dinero deben destacarse los agitadores famosos: Marcelo del Pilar, abogado de Bulacán y residente en Barcelona desde 1888 y José Rizal ${ }^{12}$.

En el citado Archivo de PP. Agustinos de Valladolid, hemos encontrado un diploma expedido por la masonería de Lima en el que se contiene el nombramiento a un alto grado: el de "Perfecto y $\mathrm{Su}$ blime maestro", en favor de un individuo cuyo nombre y firma autógrafa aparece por dos veces borrado $\mathrm{y}$, en tal forma que no hay posibilidad de interpretación. Lo traemos a colación con el fin de que se vea la directa comunicación que existía entre las distintas logias españolas, americanas y filipinas ${ }^{13}$.

Debemos consignar, igualmente, cómo no satisfechos con haber llevado sus ideas a tantos millones de indígenas, y deseando dar cima a su obra, contaminaron a la mujer creando logias femeninas. $\mathrm{Pa}$ ra ello bastaron argumentos, halagaron la vanidad de la joven y la

11. MANUEL SASTRON: O. c. 46.

12. Ibid. 47.

13. Archivo Agustinos-Filipinos núm. 3985. 
lanzaron por los caminos de la propaganda. El fundador de esta logia de mujeres fue - nos dice el autor del Katipunan- el agente de negocios Faustino Villarruel, hombre vividor en esta clase de negocios masónicos, que no tuvo inconveniente en sacrificar a su hija Rosario, joven vivaracha y experta, en aras de la más inicua de las villanías. Rosario Villarruel fue iniciada en la masonería en Hong-Kong, vecina colonia inglesa, y ya en el ejercicio de sus funciones, se erigió en venerable de la primera logia de mujeres que en el Archipiélago se ha establecido, conquistando y atrayendo a muchas de sus amigas, jóvenes mestizas, de escasa o ninguna instrucción, aunque aparentando tener una relativa enseñanza, que mejor empleada hubiera estado haciendo ellas excelentes madres de familia y dignas compañeras de un hombre honrado.

No es posible perdonar a Faustino Villarruel el crimen nefasto que cometió al prostituir a su hija entregándola, en el período álgido de su inocencia y de su candor, a las luchas sociales y a la ridícula tarea de organizar una logia de mujeres, haciendo causa común con los separatistas que se preparaban para la guerra" ".

Uno de los hombres más funestos, dentro del tema que nos ocupa en este capítulo, fue Don Miguel de Morayta. Sobre él pesan importantes responsabilidades. Si Morayta se hubiera percatado de la felonía que cometía al proteger a los masones indios y mestizos y a la sociedad hispano-filipina estamos seguros de que hubiera abandonado a los unos y a la otra a sus propias iniciativas.

De sus amigos íntimos y más elegidos brotaron los más encarnizados enemigos de España; ellos fueron los que publicaron en $\mathrm{Ma}$ drid y Barcelona "La Solidaridad», periódico filibustero y últimamente "El Kaalayan», periódico escrito en tagalog que se editaba en el Japón. Ellos alentaban a los masones de aquí, organizaban los trabajos de las logias, y vinieron elaborando la revolución, teniendo como auxiliares de ella esa gran falange de masones que por todo el archipiélago anidaba.

El historiador de la secta masónica en Filipinas termina con las siguientes palabras: "Si todo esto lo ignoraba Morayta, había que hacerle justicia, diciéndole que estaba muy ciego; y si lo sabía, y lo

14. “El Katipunan", 18-19. 
consentía y apadrinaba, séale el remordimiento leve y la Patria exíjale la cuenta que está obligado a rendir» ${ }^{15}$.

A este propósito no deja de ser interesante la larga carta que Marcelo H. del Pilar, uno de los principales cabecillas de la revolución filipina, escribe desde Madrid, en Noviembre de I894, a los amigos masones de la logia denominada "La Modestia». La carta en resumen, viene a decir lo siguiente: El filibustero agradece el apoyo moral y material que le prestan en la campaña de propoganda y de la cual se siente jefe y primer responsable. Los triunfos que van consiguiendo tanto en la opinión pública como en los organismos oficiales animan a todos los n̂lipines para seguir adelante en la tarea emprendida.

Teme, sin embargo, el que las fuerzas revolucionarias, en lugar de unirse cada día más, se dispensen unas por retraimiento y otras por indiferencia, citando algunos casos y ejemplos que comprueban su desconfianza y recelo.

Echa en cara esta cobardía a sus paisanos y los anima a continuar en la lucha pues, aunque los enemigos sean poderosos, sin embargo, sus armas son impotentes para contener la insurrección.

Sobra a los filipinos dignidad y vergüenza para realizar la redención que esperan y no necesitan por ende, ayuda del chino Palanca. Lo que hace falta es una decidida voluntad y redoblar los esfuerzos "para disimular el hueco en nuestras filas»... somos pocos; disimulemos la ausencia de elementos tan valiosos como nos han abandonado",

Marcelo $H$. del Pilar se extiende luego en dar largas disposiciones y normas a los dirigentes, y termina dando de nuevo las gracias a sus compañeros y haciendo votos porque éstos logren encauzar el bien de la humanidad y de la patria por las corrientes de la fraternidad $^{16}$.

Todos cuantos estamos enterados de la trama que se estaba urdiendo contra "los frailes» en Filipinas sabían por una parte que Marcelo H. del Pilar era cabecilla principal y por otra conocían, asimismo, la amistad intensa que existía entre este furibundo filibustero y el «Gran Oriente Español» Sr. Morayta.

15. Ibid. 21-23.

16. En Jose M. dei Castillo, op. cit. 24-34. 
También sabía que por los días en que el citado Marcelo $\mathrm{H}$. del Pilar escribió la larga carta que acabamos de transcribir, había decaimiento y se notaban dispersiones en las filas masónicas y revolucionarias. Pero entonces no se había pensado en el "pacto de sangre", que fue como el áncora de la revolución, principio fecundo del fanatismo que penetró en las ciudades, en los pueblos, en las aldeas, en todos los lugares donde se podían reclutar gentes, donde se podían afiliar asesinos.

Otro de los nombres que debemos sacar aquí, influyentes como pccos en la insurrección, sólo que esta vez español y desde España, es el de Montero Ríos. Su código revolucionario, aplicado con ligeras variantes en las Filipinas, trajo una gran perturbación; porque, además de reconocer que se necesitan leyes más rigurosas para mantener a raya todo desmán, es injusto en la aplicación del derecho; pues mientras el Código Civil concedía iguales derechos a los unos que a los otros y su doctrina era común a naturales y peninsulares, el Código penal establecía diferencias en uno de sus artículos, concretamente en el once, atenuándose o agravándose las faltas y los delitos según quienes sean los autores de los mismos, ya peninsulares, ya indígenas.

Es evidente que esta legislación entrañaba una manifiesta inmoralidad. Porque no pueden ser análogos los derechos y distintos los deberes. Si la ley es una, todos los individuos que caen bajo la misma estarán obligados a ella; lo contrario es un vicio, una inmoralidad, una perturbación.

Los nativos supieron aprovecharse de tales derechos y primacías, consiguiendo títulos académicos en la Universidad de Santo Tomás. A este propósito es interesante lo que dice el historiador José M. del Castillo: "....de los indígenas y de la raza mestiza hemos hecho abogados, médicos, farmacéuticos, notarios, procuradores, escribanos; y además hemos dado participación en la administración del Estado en calidad de oficiales, de jefes, de consejeros, de militares, de jueces, fiscales y magistrados, y hasta hemos hecho sacerdotes, elevándoles a la suprema dignidad de ministros de Dios. Sirva esto de generoso ejemplo a las naciones que quieran saber cuál ha sido y es la hidalguía de los españoles y su cristiano y liberal sistema de colonización; pero de este preclaro ejemplo, si en teoria filosófica es el mejor sistema, en la práctica es el más ruinoso y contraproducente. Porque esos indios, 
llevados a otra clase social de la que figura el resto de sus semejantes, han sido en su mayor parte, o filibusteros de acción, o platónicos separatistas ${ }^{17}$.

Al final y conforme transcurre este capitulo de las causas de la insurrección, habrá que decir que todos hemos puesto las manos en el sagrado rostro, que todos tenemos alguna culpabilidad en estas cosas tan tristes y tan dolorosas: los gobernantes de Madrid, porque no han sabido legislar teniendo en cuenta la idiosincrasia y manera de ser de un pueblo que desconocen por completo: los gobernantes españoles en Filipinas, más atentos a sus asuntos particulares, que a los públicos y necesidades del pueblo encomendado a sus menguadas dotes de gobierno.

¿Pudieron ser también "los frailes españoles» residentes en Filipinas, ya de un modo indirecto, ya directamente y debido a su conducta poco ejemplar? Un historiador del prestigio de Soldevila ha dejado escrito en su "Historia de España) lo siguiente: (El éxito de la masonería en Filipinas se explica porque la colonización española tenía allí aún un carácter esencialmente misional, y era el fraile el que principalmente representaba a España a los ojos del indígena, no siempre lo bastante dignamente) ${ }^{18}$.

Y el nada sospechoso Gabriel Maura y Gamazo dirá a este propósito: "No escasearon en ninguna comunidad los piadosos varones de celo y virtud ejemplares; pero muchos de sus individuos dieron también en la remota colonia ejemplos nada edificantes de lujuria y codicia ${ }^{19}$.

De haber leído estos textos el agustino P. Zamora, autor del libro ya citado sobre las "Corporaciones religiosas en Filipinas", seguros estamos de que no le hubieran hecho gracia alguna. Pero nosotros debemos ser más imparciales que los defensores a ultranza de las instituciones religiosas y civiles españolas en el lejano Archipiélago de Magallanes. Pero oigamos también al P. Zamora. "Sobre tres bases descansaba en Filipinas la dominación española con sus instituciones

17. Ibid. 72 .

18. Soldevila, "Historia de España", (Barcelona) 1959), VIII, 387.

19. G. Maura y Gamazo, "Historia crítica del reinado" de D. Alfonso XIII durante su minoridad..." (Barcelona 1919) 292. 
y organismos: la religión, el prestigio de los párrocos regulares y la superioridad de raza $\tan$ conforme con la hidalguía española».

Y luego se pregunta si serán "los frailes» culpables de la pérdida de Filipinas. Para contestar con un largo comentario que nosotros resumimos de la siguiente manera: Las logias masónicas, establecidas en el país por españoles, fomentadas por españoles y propagadas por españoles se encargaron de echar por tierra la primera y más sólida de las bases enunciadas: la Religión. En las logias oyeron los indios la palabra independencia y rebelión. En ellas se creyeron capaces de gobernar las islas igual o mejor que los españoles. Surgió en ellos el deseo y la ambición; el amor a la independencia del país; idea ésta que cegó y ofuscó sus mentes hasta impedirles ver la traición, la ingratitud y la felonía que cometían contra España.

Parece ser que el mayor obstáculo a sus fines -sigue comentando el P. Zamora - lo encontraron en los institutos religiosos; y de ahí que las logias masónicas les declararan una guerra sin cuartel; guerra hipócrita y subterránea, oculta bajo el manto de la legalidad, en reformas de leyes y reglamentos, con tendencia a hacer el vacío en derredor del párroco regular.

La otra base, tercera de las apuntadas, que sostenía en Filipinas la soberanía española era la superioridad de la raza; pero ésta desapareció paulatinamente a los golpes demoledores de la piqueta masónica.

No nos convence el P. Zamora cuando parece defender en su alegato que nunca se debiera haber dado entrada a los indios en los puestos claves del gobierno del país, aunque es cierto que no estaban todavía lo suficientemente preparados y maduros para tan importante como delicada tarea. Como no pueden convencer a nadie -al menos hoy- estas líneas con las que el agustino cierra uno de sus más elocuentes párrafos : “...la superioridad de raza, necesaria para la conservación de las colonias, había desaparecido por efecto de las leyes y por la degeneración moral de la raza conquistadora. No había crecido el nivel del indio "que tan chato es hoy como fue siempre», sino que había bajado el del español hasta igualarse al del indio)" ${ }^{28}$.

Más justo y más imparcial nos parece el juicio del P. Graciano Martínez, el cual, en este capítulo de faltas y culpas no exime ni ex-

20. E. Zamora; "Las Corporaciones religiosas en Filipinas, 431. 
cluye a las corporaciones religiosas, antes, por el contrario, nos viene a decir que sobre ellas recae gran parte de responsabilidad del desastre "En los altos puestos de esta floreciente colonia - escribe textualmente- hacía ya tiempo que no se miraba mucho por la honradez tradicional de España.

$\mathrm{Y}$ no se vaya a creer que exima de toda responsabilidad a las corporaciones religiosas. Soy más imparcial que todo eso. Bien que muy poca, alguna culpa les cabe. Viéndose como se veía con luz clarísima el sesgo que iban tomando las cosas de algunos años a esta parte por la vista de ciego que respecto de ciertas campañas tenía la vigilancia pública, las corporaciones, pensamos humildemente, debieran elevar un manifiesto a la nación donde, al par que se patentizasen los ataques desembozados y las tenebrosas urdimbres con las que autoridades de aquende empujaban al genuino amante de la patria hacia la sima del descrédito, y la actitud amenazadora y levantisca que, en vista de tamaños excesos y de $\tan$ insidiosas cruzadas, iba tomando el trabajado pueblo filipino, se plantease el siguiente dilema: o la nación envia a estas islas hombres decentes que practiquen y hagan practicar la justicia, o nosotros estamos demás en el Archipiélago. Y o hubiéranse corregido los abusos, estabilizados nuestros dominios, o hubiesen podido los frailes erguir muy alta la frente, pura y limpia de la más leve mancha. Gobernando como se gobernaba aquí, no se necesitaba tener ojo muy avizor para ver que esto se nos iba de entre las manos) ${ }^{21}$.

Dice bien el P. Graciano, cautivo del Katipunan durante dieciocho meses. Pero nosotros no sólo culpamos a los religiosos por cuanto no dieran la queja oficial y colectiva viendo y previendo la catástrofe, sino que culpamos a algunos de su negligencia y abandono en muchas de sus tareas apostólicas; les culpamos de su indolencia y comodidad y vida poco mortificada; y culpamos a unos y otros de su vida poco edificante.

Por desgracia, los filibusteros sabían más de la cuenta de la vida de muchos religiosos, sobre todo del clero secular. $Y$ atacaron a la iglesia contra toda justicia y razón, pero muchos hechos hubieron de ser admitidos.

21. G. Martinez, "Memorias del Cautiverio", (Manila 1900) 53. 
Con todo, no debemos tomar en serio lo que la prensa filipina afirmaba por aquellos agitados días.

Alegan ciertos periódicos que "los frailes) fueron los culpables de la pérdida de Filipinas. Ellos quienes provocaron la insurrección contra la metrópoli; ellos quienes entregaron la plaza de Manila a los yanquis; ellos quienes pagaron los veinte millones de dólares, por lo que en público mercado fueron subastados los moradores del país; ellos quienes eran los prototipos de la ignorancia, de la inexperiencia y de la tiranía; ellos los autores netos de todos los latrocinios y los causantes genuinos de todos los fusilamientos.

Hemos aludido ya en este capítulo a otro motivo inspirador de la insurrección: el afán de independencia. Los intelectuales filipinos hacía tiempo que soñaban con la independencia de su pueblo, lo mismo que lo habían soñado y conseguido, tiempo atrás, en los pueblos hispánicos de América. Harto elocuente resulta la confesión de uno de los principales insurrectos. Se trata de Valentín Díaz, secretario del famoso cabecilla Macabulos. Este hombre, oriundo de Ilocos, ya entrado en años, pasados en su mayor parte en Manila, regordete y de ojos traviesos, había llegado nada menos que a ser "directorcillo" del Tribunal de Tondo, cuando la insurrección de 1896 . Había sido impuesto por el general Aguinaldo como secretario de Macabulos, y dicen malas lenguas - habla ahora otro prisionero del Katipunan, el P. José Rodríguez de Prada, en sus "Memorias de un prisionero"- que con el objeto de que espiara y fiscalizara los actos que este cabecilla, de quien no fiaba mucho el "Presidente de la nueva República». Pues bien, este personajillo, pasado ya todo, independiente Filipinas, se presentó un buen día a varios de nuestros religiosos y les soltó a quemarropa: (no se si ustedes recordarán lo que ocurrió en Malacañag cuando Despujols era Capitán General. Cierto día que se celebraba el cumpleaños de la generala (a cuya reunión casi sólo asistieron indígenas), cuando los salones estaban más concurridos y todos satisfechos y muy animados, yo y otros compañeros que allí estaban nos reunimos en uno de los balcones, y después de apagar las luces para no ser conocidos, gritamos todos a una: ¡abajo los frailes! i Mueran los frailes! Pero, Padres, les soy a ustedes franco; ahora que ya somos libres y España no puede castigarnos, lo que menos importaba a los filipinos eran los frailes : queríamos echar de aquí a los españoles para ser independientes. Ustedes no eran más que una pantalla que nosotros 
poníamos delante para ocultar nuestra verdadera intención: la cual, manifestada claramente, sería entonces nuestra ruina) ${ }^{22}$.

Como final de este capítulo, sólo nos queda referir dos documentos encontrados en el Archivo de Agustinos-Filipinos de Valladolid, que dicen relación con el asunto que nos ocupa. Extractamos.

En Febrero de 1898 , la Colonia Filipina residente en Madrid, se dirigió a la Reina y a la nación española con un "Manifiesto-Programa), pidiendo, a imitación de las colonias americanas, la indepen. dencia del Archipiélago: Piden que se ponga remedio inmediato y se cicatricen las heridas abiertas a causa de la insurrección. Alegan y har cen protestas de su amor a España y del deseo que les mueve de que los filipinos sigan perteneciendo a España.

El manifiesto que lanzan al viento quiere evitar que sa pierdan las colonias por el trato despótico que sus habitantes reciben, llamando la atención sobre América, y cómo y porqué se perdieron aquellas repúblicas.

Los filipinos - dicen - no se pueden gobernar como se gobernaban en los días de Legazpi, cuando España se regía por instituciones absolutistas, y sa tardaban seis meses en llegar de la Metrópoli al Archipiélago. Hoy esto es inadmisible, y más teniendo en cuenta que muchos naturales han viajado por Europa y han estudiado $y$ conseguido títulos en universidades europeas.

Estos hombres, cuando vuelven a su país, no pueden encontrar. se a gusto en aquella atmósfera teocrática y llena de absurdos.

La insurrección nunca ha pretendido romper los estrechos lazos que unen a Filipinas con España. Y por lo que hace al "Katipunan", éste se creó para derrocar únicamente el poder teocrático y su indispensable cortejo de injusticias y de tropelías. Nada ponía en peligro la insurrección tagala, sino la existencia de las órdenes religiosas.

Hacíase ya muy difícil - continúa el manifiesto filipino- la continuación del "Statu quo"; mas la inquina con que se ha perseguido a tantos millares de inocentes, le han hecho de todo punto imposible.

Ante el empeño de acudir al gobierno de Madrid con peticio69 .

22. G. Rodriguez de PRada, "Memorias de un prisionero" (Madrid 1901) 
nes de reformas, algunas entidades y publicistas distinguidos han dicho: "ya es hora de que oigamos la voz de los filipinos". Las reformas que querían los insurrectos son lo que queremos los filipinos que no hemos tomado parte en la insurrección ni somos protegidos de los frailes ${ }^{23}$.

El otro documento que va unido al anterior se refiere a una importante (memoria), manuscrita, y obra del religioso agustino, P. Moisés Santos, la cual está fechada en 1897 y lleva por título: "Importancia de la cuestión agraria en la revolución filipina).

En dicha memoria se nos hace ver con argumentos irrefutables cómo los gobiernos de Madrid llevaban mucho tiempo sin enterarse de lo que ocurría en el campo de aquellas colonias tan lejanas y menos ricas que Cuba y Puerto Rico. Este desconocimiento de la cuestión agraria de Filipinas hizo que cuando se pusieron a dictaminar normas y a hacer reformas de tipo administrativo lo hicieron mal. Y esto precisamente, este desenfoque del problema agrario - concluye el misionero agustino - fue otra de las causas de la insurrección tagala ${ }^{24}$.

El Katipunan, asociación formada a imitación de la masonería y que se adoptaba divinamente a la mentalidad y a los instintos tagalos ${ }^{25}$, con sus (pacto de sangre), y sus miembros, activos y temibles como ningunos, aprovechó todos estos motivos y concausas de insurrección y consiguió sus fines de independencia más fácilmente de lo que ella misma se lo prometía.

23. Archivo de Agustinos Filipinos, n.. 4030.

24. Ibid:

25. F. Soldevila, "Historia de España", VIII, 387. 
b.-Chispazos revolucionarios durante el siglo XIX.

En realidad, desde que los pueblos americanos se levantaron contra la metrópoli, reclamando su mayoría de edad, Filipinas vivió ya en antecedentes de sublevación. Cierto que fueron solamente chispazos y pequeñas insurrecciones fácilmente vencidas y sofocadas, pero ello indicaba que, más pronto o más tarde, el pueblo filipino tenía que seguir los pasos del americano. En esto, quizá no estuvieran del todo avisadas las autoridades españolas, y a fe que las mismas corporacio. nes religiosas tampoco fueron previsoras, si bien hay que confesar en honor de las mismas que barruntaron siempre el peligro. En conjunto, ni unas ni otras supieron estar a la altura de las circunstancias, preparando al indígena para cuando llegara el momento crucial, el día señalado.

Como antecedente de la revolución independentista, ya en 1807 , con motivo de los desaciertos políticos de Carlos IV, de Godoy y de la reina M." Luisa y del propio Príncipe de Asturias, luego Fernando VII, estalló una sublevación en la provincia de Ilocos, la cual al principio fue dominada con facilidad por los misioneros, que se pusieron, como siempre al frente de los pueblos leales, pero luego volvió a renacer con más brío, apoderándose los insurrectos del pueblo de Pigdig y derrotando en aquel lugar a las fuerzas leales. Un religioso agustino, párroco del pueblo de Betal, nos cuenta cómo estando predicando a sus feligreses y exhortándoles a la obediencia y vasallaje al rey de España, se levantó una mujer a contradecirlo, diciendo que no creyessn al cura; que todo eran embustes, "que con el título de Dios del Evangelio, y del rey, no haciamos más que engañarlos para que los españoles los desollasen y chupasen la sangre, pues éramos los frailes españoles como los demás» ' ${ }^{\prime}$

Otro levantamiento de las mismas características que la anterior estalló en el mismo territorio el año I8I I. El pretexto fue un deseo insensato de cambiar de religión. La nueva creencia se centraba en la adoración de un dios muy curioso, denominado "Lungao". Los principales cabecillas de Barangay entraron en tratos con los igorrotes y demás salvajes de Cagayán con el fin de acabar con los españoles. Pe-

1. Cit. en "Los Frailes Filipinos" 99. 
ro otra vez la insurrección quedó abortada gracias "(a los frailes» españoles, los cuales avisaron al gobierno, desbaratando a tiempo la trama ${ }^{2}$.

Â principios de 1814 el general Gardoqui, autoridad máxima a la sazón en el Archipiélago, se empeñó, contra el deseo de los religiosos que conocían mejor que él a los indios, en publicar la constitución de I8I2. Los indios no interpretaron bien la igualdad que se establecía en ella y empezaron a insurreccionarse negándose a pagar el tributo y las contribuciones que sobre ellos pesaban. No querian reconocer la autoridad de los gobernadores y en algunos pueblos de Ilocos llegaron a poner en libertad a los presos. Abolida la Constitución por Fernando VII, los indios creyeron que se trataba de una intriga más de los españoles y de los misioneros para privarles de la igualdad de derechos que tanto apetecían.

Los sucesos políticos acaecidos en la península de 1820 a 1823 debían tener eco también en Filipinas. Descubierta en la primera fe. cha aludida una conspiración por varias mujeres que la denunciaron, tuvieron que ser enviadas a España varias personas, entre las que figuraban algunos oficiales del ejército; pero quedaron en el Archipié. lago otros cabecillas importantes, como el famoso capitán filipino Novales, el cual reanudaría los hilos de la conjura. El auditor de guerra pedía que Novales fuese también desterrado y vigilado como hombre peligroso, pero el general Martínez, hombre bondadoso, se contentó con mandarle a Mindanao a perseguir piratas en la provincia de Cagayán. Lo cierto es que Novales no salió para su nuevo destino ${ }^{3}$.

El 2 de junio de 1823 se reanuda la conspiración. Un mestizo y conspirador, por nombre el teniente Ruiz, hace guardia en el palacio del capitán general, al mismo tiempo que un hermano del cabecilla Novales la está haciendo en el fuerte de Santiago en Manila.

Por fortuna, el general Martínez se encuentra fuera de la ciudad, descansando en su casa de campo, en Malacañang, pues era la

2. Ibid. 99 .

3. Según el autor de "Estado de Filipinas", no llegó a embarcarse por el mal tiempo; pero, según Mr. GrRonNIere, parece que embarcó; si bien regresó en seguida a Manila. GIRoNNIERE es autor del interesante libro "Aventures di un gentil homme bretón aux iles Philippines" (París 1853). 
época de los grandes calores en el Archipiélago. Los amotinados, conpletamente libres y sin vigilancia alguna a pesar de los prudentes avisos de los religiosos a las autoridades competentes, asesinan a mansalva al trniente Folgueras, escapando con apuros de una muerte segura el coronel Santa Romana, y cayendo prisioneros muchos oficiales españoles que hacían mofa días anteriores de las predicciones de los frailes.

Los gritos de triunfo de los rebeldes despiertan al mayor de la plaza, Duro, que corre valerosamente a la puerta de Parián, toma la guardia que allí había, entra con ella en el cuartel de los amotinados y castiga duramente la insurrección.

Cuando regresa Novales, se encuentra con la puerta cerrada por su propio hermano. Pero él se hace fuerte en la iglesia-catedral y en el ayuntamiento, hasta oue abandonado de' sus tropas fue hecho prisionero juntamente con el teniente Ruiz en el arrabal de Tondo. Pocas horas más tarde caían fusilados juntamente con otros veintitrés rebeldes *.

Nuevas conspiraciones se registraron en los años 1828 y 1836 .

La primera fue promovida, como la anterior, por dos oficiales del ejército, que se pusieron al frente de un movimiento separatista surgido en Manila a consecuencia de la interpretación que daban a la Constitución de Cádiz.

Reviste capital importancia los movimientos subversivos de 1836 y 1837 por la relación que tiene en los desgraciados acontecimientos de España. Son los años de la minoría de edad de Isabel II y de la Regencia de María Cristina. Los años en que la lucha dinástica escinde los campos - carlistas y cristinos o isabelinos- terminando por imponerse el régimen liberal. Los años en que el sectarismo religioso llega a extremos insospechados por las simpatías que el clero epañol muestra hacia la causa carlista. Los años de la (matanza de frailes) en Madrid, acusados de haber envenenado las fuentes y ser causa del cólera asiático que hacía estragos en la capital de España. Los años en que es extinguida de nuevo la Compañía de Jesús y suprimidos la mayor parte de los conventos de España. Los años del gobierno de Mendizábal y su célebre "desamortización eclesiástica».

4. "Los Frailes Filipinos", 101-102. 
Pero son los años también del «Motín de la Granja», cuando sustituido Mendizábal por Istúriz, el partido progresista se lanza por el peligroso camino de la intriga y de la conspiración, consiguiendo soliviantar, con engaños y promesas, a los sargentos de la cguardia raal», que se amotinan en el Real Sitio y proclaman por tercera vez la Constitución de 1812 .

Estos acontecimientos repercuten en las colonias de ultramar. En Filipinas, el gobernador Salazar se las ve y desea para contener a los indios que, como consecuencia del "Motín de La Granja» y de la exclaustración") se han dividido en dos bandos: los que desean que salgan del Archipiélago misioneros y todos los españoles por igual; y los que son partidarios de que sean expulsados solamente los "castilas) quedando con ellos los misioneros. Los mismos españoles fueron motivo de nuevos conflictos, pues mientras los exaltados querían implantar la Constitución, los moderados creían peligroso introducir reformas políticas de tanta trascendencia en la colonia.

De todas estas cenizas mal apagadas surgió en tiempo del general Oraá, una nueva revuelta, esta vez con matiz religioso. Nos referimos a la sagrienta insurrección de Tayabas, que fué capitaneada por el donado, o aspirante a religioso, Apolinario de la Cruz, del Convento de San Juan de Dios, de Manila, un indio puro, el cual con pretexto de formar una gran cofradía en que no se admitía ni siquiera a mestizos, ni a los chinos, había reunido a unos cuatro mil indios, poniendo en peligro la paz y el dominio español de las islas.

Apolinario se hacía llamar el "Rey de los tagalos" y predicaba a éstos que bajaría del cielo una virgen tagala para casarse con él. Prometió mantener con un poco de arroz a cuantos indios le siguieran $y$ les decía que no temiesen a las balas de los españoles, pues no les harían daño alguno.

La sublevación fue descubierta por el cura de Lucban y otros frailes franciscanos. Se presentó en seguida el alcalde para someter por las buenas al rebelde, pero éste le contestó con una descarga que lo dejó muerto en el acto y fue, a la vez, como el grito de alarma de los indios que siguieron hipnotizados a su jefe. Como era de esperar, la torpeza de los mismos indios hizo que se entregaran en seguida a las tropas españolas que acudieron al lugar de la rebelión. 
El devoto Apolinario fue entregado por sus mismos partidarios y pasado a cuchillo junto con otros trescientos de los sublevados.

En 1854 los trastornos políticos de España tuvieron otra vez fatídica resonancia en el Archipiélago filipino. Ahora le tocaba ser cabecilla de rebelión al mestizo Cuesta, el cual había sido educado en España. Cuesta aprovechó su cargo de comandante de carabineros de la provincia de Nueva Ecija para levantarse contra la autoridad. En unión con otros separatistas de Manila, concibió el plan de una vastísima conspiración contra la Metrópoli. Para ello soliviantó los pueblos de su demarcación y levantó en armas a las fuerzas de su mando al grito de "¡Muera España y viva Filipinas libre!» El astuto cabecilla pretendía llamar la atención del gobierno de Manila sobre los planes de Bulacán, Pampanga, Nueva Ecija y Pangasinán. Aprovechar entonces las pocas fuerzas que quedasen en Manila y sublevar a esta ocasionando un conflicto general en toda la isla de Luzón, que había de ser secundada por la de Bisayas. Capturado el rebelde fue puesto en capilla y ahorcado en Manila el mismo año 1854 .

Nueve años después, siendo gobernador general de las islas don Rafael Echagüe, se fraguó otra conspiración, esta vez para minar la influencia de los frailes. Poblados y ciudades fueron inundados de hojas volantes y libelos infamatorios escritos en dialecto del país 6

La revolución de 1868 fue recibida en Filipinas con gran entusiasmo. Era entonces gobernador General cel prudente y gran patriota Gándara", el cual, avisado por los religiosos de los nuevos movimientos revolucionarios que se advertían en distintas ciudades, reunió una Junta General, convocando a ella a todas las personas más notables de Manila y a los provinciales de las órdenes religiosas. El resultado de la misma fue tomar severas medidas contra los supuestos sublevadores y vigilar de cerca a los peligrosos.

5. Como en tantas ocasiones, la conjura fue descubierta por los religiosos agustinos, curas párrocos de Manila, Agonoy y San Isidro, los cuales, después que avisaron al gobierno de Manila, fueron presos por los soldados de Cuesta, y condenados tras un consejo de guerra habido entre el cabecilla de rebelión y varios sargentos indigenas. Pero los indios, respetuosos con los misioneros, no sólo no cumplieron la orden de fusilamiento, sino que les facilitaron la fuga ("Los Frailes Filipinos" 105)

6. El que más animaba la conspiración era el clero nativo, quejoso de las comunidades religiosas por la tan debatida cuestión de "los curatos", la cual puede dar materia por si sola para un interesante trabajo de investigación. 
Los indios creyeron que la "Revolución) -para ellos algo así como un nuevo emperador de la China, o algún alto personaje- había decretado que todos los hombres eran iguales y que ya no había diferencia alguna entre filipinos y españoles. Por lo que éstos tenían que volver a España sustituyéndolos ellos en todos los cargos políticos y empleos de Administración y Hacienda. Creían más, que en breve el Papa nombraría obispos filipinos y curas suficientes nativos, por lo que los misioneros españoles también estaban sobrando en el archipiélago. El nuevo capitán general se había de casar con una hija del pueblo filipino, la cual nombrada princesa, habría de dar hijos que fueran los futuros reyes del indio.

Las cosas no pasaron adelante. Solamente unos pueblos de la isla de Luzón dieron muestras de inquietud, especialmente Cavite, agitados y conmovidos por clérigos indígenas y abogacillos que corrían de un lugar a otro sembrando la semilla del descontento y de la insurrección.

Años adelante, 1872 , tendría lugar la sublevación de Cavite, a la que ya nos hemos referido al tratar de este prestigioso general español y gobernador de Filipinas. $\mathrm{Y}$ allí vimos los intentos del cabecilla Soro que mantuvo un reñido combate con la guardia civil de Imus. Fue aquella una insurrección militar que se pudo contener gracias a la rapidez con que actuó el general Izquierdo. Pero aquello fue un toque de alarma y un grave síntoma de lo que pudiera ocurrir después. Cierto que ni esta insurrección de Cavite, ni los movimientos revolucionarios de 1888 , tienen que ver directamente con la gran insurrección de I896; pero ello denota el estado de cosas del Archipiélago y cómo se podía temer cualquier catástrofe en Filipinas y hasta una guerra y sublevación general, como estaba ocurriendo en Cuba.

El continuador de la historia de Lafuente - Juan Valera- nos dice expresamente que el levantamiento de Cavite produjo una honda impresión en Manila, trocándose a poco en temor por la significación y trascendencia que aquel hecho tenía. "Era la repetición del grito emancipador que otros habían dado anteriormente, más o menos velado; pero siempre ingrato por lo mucho que debian a los españoles, no sólo los curas indígenas, sino todos los pobladores de aquel país, que no fueron en un principio otra cosa que hordas de salvajes, como lo son hoy los igorrotes y demás indios refractarios a toda civilización. 
La insurrección de Cavite debió haber estallado en tres puntos diversos, aprovechando la ocupación de nuestra escuadra y nuestras tropas en Joló : faltó aliento a aquellos revolucionarios y se acudió con fuerzas a dominarlos, sucediendo al triunfo los merecidos castigos; porque, además de exigirlos la insurrección, los reclamaban los manes de las víctimas por los insurrectos sacrificados al grito de: jMuera el Castila! ¡Viva la independendencia! ?.

Consecuencia de la insurrección de Cavite, fue el motín que tuvo lugar en el presidio de Zamboanga, donde sufrían condena muchos de los sublevados. Esta vez los mismos moradores, el púeblo en masa de aquella villa se levantaron airados contra los presidiarios, los batieron en su propio recinto y ganaron, por aquella hazaña, para su ciudad el timbre glorioso de "heroica villa».

7. M. Lafuente "Historia General de España", (Barcelona 1890) XXIV 397. 


\section{LA ACCION DEFINITIVA.}

\section{a.- La conspiración de los Tagalos.}

En el capítulo anterior nos hemos referido a diversos levantamientos que pueden ser considerados como síntomas de un proceso insurreccional. Será preciso ocuparnos ahora de la culminación de todos estos episodios, que tienen su expresión en los sucesos de 1896.

El P. Bernardo Martínez, en sus "Apuntes Históricos» comienza el capítulo que se refiere a la insurrección filipina con las siguientes palabras: "He llegado a la época más triste de la historia de Filipinas, a la época del desmoronamiento, de la consunción cotal, absoluta, inestable de nuestro prestigio. El dedo de Dios había señalado la hora fatídica en la que se despojaba a la nación española de los últimos restos de sus grandezas para atravesar el período de las humillaciones y verse mezclada entre las ruinas de sus sacrificios. El cielo lo disponía así, y no hay fuerza humana que pueda contrarrestar los designios de Dios" " .

Esto es verdad; pero nosotros, que deseamos ser objetivos y escribir y hacer historia desde un punto de vista más humano y racional (-no tenemos por qué (echar mano» de la Divina Providencia cuando ésta tampoco lo pide-), preferimos tomar el hilo de la narración desde más atrás y acudiendo a fuentes imparciales e historiadores insignes que ofrecen toda garantía de veracidad.

E1 día 29 de Agosto de 1896 organizáronse los primeros grupos que lanzaron el grito de rebelión contra España. San Juan del Monte, Santa Mesa, Balintauac, Colocan y Novaliches, viéronse regadas con la primera sangre vertida en los altares del patriotismo. El zo del mismo mes fueron declarados oficialmente en estado de sitio las provincias de Manila, Bulacan, Pampanga, Nueva Ecija y otras, creándose en seguida el primer batallón de leales voluntarios de Manila.

Hay una página elocuente, escrita por el P. Tomás Espejo, y dirigida a modo de carta al M. R. P. Manuel Gutiérrez, entonces provincial de los agustinos. En ella nos habla de la expedición de Emilio

1. B. Martinez, "Apuntes Históricos de la Provincia Agustiniana del Santisimo Nombre de Jesús de Filipinas" (Madrid, 1909), XLV, 480. 
Aguinaldo, nombrado general en jefe de Cavite, por los pueblos de Taguig, Pateros y otros. El agustino se defiende y justifica ante su supericr de las torcidas versiones que habían dado acerca de la conducta seguida por él en aquellos días de difícil control. El mismo P. Provincial le había exigido aquel escrito para que (en conciencia) dijera y declarara la verdad. El resultado de todo ello fue conseguir un documento precioso y de primera mano para el fin que nos hemos propuesto ${ }^{2}$.

El documento trata diversas cuestiones. Primeramente, pone en conocimiento del Superior Mayor cómo mucho antes de que estallara la sublevación tagala, él y otro compañero del pueblo inmediato avisaron repetidas veces a la Guardia Civil del peligro que corrían aquellos pueblos y de las comunicaciones clandestinas que existían entre los insurrectos de Gavite y de Manila. A pesar de todo lo cual, las autoridades y los encargados de velar por el orden no hicieron caso alguno. Seguidamente, da cuenta de las numerosas partidas de insurrectos que se echaron al monte cercano organizando desde alli la revolución. La Guardia Civil sigue sin enterarse de nada. Hasta que se oyeron los primeros disparos en el pueblo de Taguig produciendo una gran confusión en el destacamento al cogerlo desprevenido.

Las gentes sencillas y desarmadas corren a refugiarse en la iglesia y convento como lugares más seguros, o huyen a los montes, de donde descendían hacia el pueblo los insurrectos vociferando, corriendo y disparando al aire sus rifles.

Llegados al pueblo y ya ante la presencia del misionero y de las gentes que le rodean aterrorizadas, le dicen que no debe pasar miedo, que han recibido orden de su jefe Emilio Aguinaldo de respetar sus vidas y no causar daño alguno.

El misionero estaba dispuesto a defenderse con las armas. Los insurrectos comienzan por pedir las que existieran en el convento. Se les dijo que allí no había arma alguna; pero ante la insistencia de aquellos, no hubo más remedio que entregarles todas. Después, obli-

2. Resulta que el P. Manuel Gutiérrez, deseando saber la marcha de los acontecimientos, envió a sus religiosos una circular pidiéndoles detalles de la insurrección en su respectiva parroquia. Los religiosos se lo contaron por carta. Estas cartas han venido a parar al Archivo de los Agustinos Filipinos de Valladolid y constituyen un material de inapreciable valor para nuestro trabajo. 
garon a los indios a hacer trincheras y defensas para el ataque que se preveía de las fuerzas españolas. Hasta que, llegada la noche, se presentó en persona el propio Aguinaldo, acompañado de titulados generales, brigadieres y coroneles.

El P. Tomás Espejo hace un breve retrato, objetivo y gráfico, del general en jefe de los insurrectos, el cual se mostró amable y cortés y hasta dio detalles al misionero y a los que con él estaban de la marcha de la insurrección y de los consejos de guerra que se habían formulado ya contra algunos religiosos de la Orden de San Agustín residentes en Filipinas.

El'P. Tomás Espejo, pareciéndole que Aguinaldo era esta vez sincero, se atrevió a preguntarle por el número de combatientes que traía consigo, a lo que contestó el general filipino que sólo traía 1.0oo hombres, de los cuales 500 venían armados con rifles y los 500 restantes con armas blancas. La verdad es que sólo contaba con 150 fusiles remington y unos cuantos rifles y escopetas de caza y algún que otro revólver. En Cavite - decía Aguinaldo- tengo a mis órdenes roo.00o hombres y sólo deseo que el general Polavieja dirija las operaciones militares de esta región.

El documento se extiende luego en pormenores que no vale la pena contar; incluso se nos narra en él cómo, invitado a cenar con los religiosos, Aguinaldo accedió de buen grado, aunque luego no tuviera inconveniente en permitir que sus ayudantes molestasen a sus amables anfitriones durante toda la noche pidiéndoles armas y dinero; y como no lo consiguiron fueron sacados del convento y conducidos a la casa donde se hospedaba el propio Aguinaldo.

Después de varios días de continuos sobresaltos, los sufridos misioneros y otras gentes sencillas acogidos a la iglesia, fueron socorridos por las tropas españolas que mandaba el coronel Ruiz Serralde. El ilustre historiador Fernández Almagro alude y trata sucintamente estos hechos que nos cuenta en detalle y al pormenor el misionero agustino cuando, a propósito de las operaciones militares llevadas a cabo por Polavieja, relata lo siguiente: "La más señalada importancia de esta victoria de las armas metropolitanas estribó en que venía a completar los éxitos logrados días antes, en Cacarnon de Sile por la columna que mandaba el comandante de Estado Mayor Olaguer Felíu, y en Taguid, cercado por unos cuatro mil hombres al mando de Emilio Aguinaldo, que lograron dar un golpe de mano sobre Peteros. 
El general Galbis liberó a Taguid, y el generalísimo filipino hubo de retirarse a Hagonoy extremadamente quebrantado $)^{3}$

Es interesante comprobar cómo el P. Espejo, sin que intente justificar la conducta de Aguinaldo, trata, sin embargo, de explicar los hechos de un modo más objetivo y razonado a como lo han hecho algunos historiadores y a como lo hizo la prensa de aquellos días. "No es que quiera justificar en este individuo (Emilio Aguinaldo) todo lo que haya hecho; el alzar bandera contra la madre Patria, a quien debe lo que es y lo que tiene, es más que suficiente para juzgarle; pero he notado en toda la prensa con propósito decidido de retratar a todos los insurrectos con los colores más subidos de la execración, no habiendo crimen que no se les atribuya, y negándoles la posesión de la más pequeña virtud, y esto no es cierto. Además, y esto quiero que se fije $V$. $\mathrm{R}$. con especial cuidado, al tratar de las cosas de la insurrección de la manera que queda indicado es para deducir otras consecuencias de capitalísima importancia, que, aunque no se han publicado por la prensa formal, corren de boca en boca entre ciertos elementos que no quiero nombrar, pero que todo el mundo conoces s.

A decir verdad, los síntomas de las gran insurrección habían aparecido ya por el año 1880 , con lo que se dio en llamar con toda propiedad "la política solapada" en lo que a la Administración pública se refiere; y también a los demás elementos que constituían la sociedad peninsular entre los indios pertenecientes a las clases principales : "tergivesando conceptos, marcando aspiraciones irreverentes y extrañas venían produciendo los indios filipinos desde la citada fecha algunos actos públicos colectivos que constituían esencialmente protesta viva contra el régimen instituido por los españoles)" ${ }^{5}$.

El citado F. Álmagro, al tiempo de estudiar el grave problema de las colonias, dice que éste no era, aparentemente, tan grave en Puerto Rico y Filipinas como en Cuba. Pero era indudable que cuanto aconteciese en la "Perla de las Antillas» repercutiría inmediatamente en la contigua isla citada, su hermana menor y también en el archipiélago filipino, donde las sociedades secretas, sin alardes políticos e intelectua-

3. M. Fernandez Almagro, "Historia politica de la España Contemporánea", II. (Madrid 1959), 352-353.

4. Archivo Agustinos Filipinos, n. ${ }^{\circ} 1126$.

5. M. Sastron, "La insurrección en Filipinas y guerra Hispano-Americana", 56 . 
les parejos a los de Cuba, no cejaban en el empeño de despertar la conciencia del indígena ${ }^{6}$.

Conforme iban acercándose las fechas en que el movimiento había de estallar, tal vez de un lado el regocijo mismo con que los conspiradores aguardaban el triunfo, y de otra parte el peso que gravitaría scbre la conciencia de algún arrepentido, las sospechas se hicieron afirmaciones concretas. Hasta que llegó el descubrimiento sensacional ${ }^{7}$.

Con la gran suma de medios - cuenta el cronista- que para hacer siempre eficaz la vigilancia tienen en Filipinas los frailes, en virtud de la mayor identificación que éstos alcanzan con cuanto es vida y costumbres en aquella española tierra, nada de extraño tiene el importante hecho de que el exacto conocimiento de los detalles relativos al estado de latente conspiración lo adquiriese y revelase inmeditamente un religioso de condiciones de actividad excepcionales, cuales las evidenciadas durante su vida honrada por el celoso Cura Párroco de Tondo, el Agustino P. Mariano Gil.

Y fue el indio Teodoro Patiño, honrado operario del «Diario de Manila» quien, presentándose al citado religioso, le ofreció detalles de la insurrección; el lugar y sitio donde podría hallarse la piedra litográfica con clave que servía para la tirada de recibos-talonarios correspondientes a la suscripción de los afiliados al Katipunan; el lugar en que se fabricaban los puñales que eran entregados a los sectarios, denunciando, asimismo, la presencia y permanencia de 1.500 hombres reunidos ya en el lugar de Tapusi, los cuales esperaban solamente la señal del alzamiento.

Descubierta la gran conspiración de los tagalos en aquella madrugada del 20 de Agosto de 1896 , los acontecimientos se desarrollaron de un modo vertiginoso. Entre la población peninsular y aun entre los insulares leales la noticia produjo indignación. El patriotismo que la mo. tivaba hubiera merecido mejores gobiernos que los que en Madrid entonces había.

Los jefes insurrectos ya no podían permanecer en el anonimato

6. F. Almagro, "Historia politica de la España Contemporánea", 332.

7. No nos podemos imaginar hasta dónde hubiera explotado hoy el sensacionalismo de la prensa el descubrimiento de la insurrección efectuado por el agustino $\mathrm{P}$. Mariano Gil, según veremos, con la importancia que se merece. 
por más tiempo. En una gran reunión de conjurados, Andrés Bonifacio dio el grito de rebelión y se echaron a luchar contra los soldados españoles, que eran escasos en Manila y más escasos en provincias por falta de previsión $y$, tal vez, en algún caso, por mala intención de los gobernantes.

El movimiento insurreccional, calificado en los primeros días de mero accidente, se convirtió pronto en sangrienta guerra, tanto más terrible y cruenta, cuanto que junto a las aspiraciones autonómicas, la motivaba el odio de la raza malaya contra la raza blanca, el espíritu de rebeldía del indio contra el español y la animosidad hacia el clero estimulado por el sectarismo masónico.

¿Cómo pudo darse la revolución?. «En Manila -escribe el autor del Katipunan- no se tenía noción de lo que era un Cuerpo de Vigilancia ni las funciones que éste estaba llamado a desempeñar; cumpliendo con su misión honrada; mejor dicho: la noción de este cuerpo policíaco la habían olvidado los que con más razón debían tener conocimiento de sus funciones y de sus resultados; en cambio, los indios conocieron su importancia al punto, e influyeron para colocar de agentes a cuatro de sus secuaces, que más tarde fueron cogidos en sus madrigueras y en la vergüenza de su delitos ${ }^{8}$.

Los filibusteros siguiercn su obra, no sin que el teniente de la Guardia Civil del puesto de Pasig, Sytiar, lo advirtiera a tiempo. En un extenso oficio al gobernador civil de Manila daba ya cuenta de la Sociedad llamada "Katipunan", de sus trabajos y de sus fines, del "pacto de sangre" " ${ }^{9}$ del número colosal de incisos que se conocían y que eran las futuras fuerzas con que contaba la revolución.

De esta comunicación oficial, como de otras anteriores, dio cuenta el gobernador civil a la autoridad suprema y gobernador general, pero éste - lo era Dn. Ramón Blanco- ni daba crédito, ni tomaba nota de esas revelaciones, sino que, por el contrario, llamaba alarmis-

8. J. M. DEL CASTILlo Y Jimenez, "El Katipunan o el filibusterismo en Filipinas", 77.

9. E1 pacto de sangre, como más adelante veremos, consistia en una incisión que se les hacía a los afiliados en el brazo, obligándose éstos a seguir ciegamente las instrucciones de la secta. En el museo de Agustinos Filipinos de Valladolid, se conserva la navajilla con que Pacheco, el supuesto Ministro de Hacienda, hacia la incisión. 
ta y miedoso al gobernador y estuvo irritadísimo y a punto de destituir al honrado teniente Sytiar.

Más adelante sería el virtuoso prior de Guadalupe el que avisara del peligro, pues un muchacho dependiente del Convento, le había denunciado que en el pueblo se celebraban unas reuniones sospechosas, que se llamaban «Katipunan». Finalmente, el cajista del "Diario de Manila», T. Patiño agraviado profundamente por una paliza que sus compañeros le habían proporcionado por diferencias surgidas con motivo de una cuota que debía abonar como socio del "Katipunan", y que se negaba a satisfacer, se quejó a una hermana que tenía en el colegio de Mandaloya, y ésta le remitió al ya citado y famoso P. Mariano Gil ${ }^{10}$.

El P. Gil volvió a su convento tranquilo y satisfecho después de haber descubierto la conspiración, sin que tal hecho haya merecido una frase de gratitud, expresiva de nobles sentimientos de ninguna autoridad; antes, al contrario, parece que en ciertas esferas causó fastidio y visible disgusto; pero el P. Gil contó siempre con los votos de la gente sencilla y del pueblo.

De la prensa no había que esperar nada, porque la previa censura la había amordazado. Cierto que algunos periódicos lanzaron algunos sueltos furibundos contra la conspiración, aun en la certeza de que iban a ser tachados; y así esos artículos no llegó a leerlos más que el cuerpo de redacción.

A este propósito, Fernández Almagro, objetivo y equilibrado, nos dice que parece que el general Blanco no dio demasiada importancia a la denuncia del P. Mariano Gil y a la que siguió poco después del recoleto Fray Mamerto de Lizasoaín, párroco de Santa Cruz, que señaló lugares de reunión y depósito de armas.

El ilustre historiador lo atribuye, bien a su espíritu, blando y contzmporizador, bien a la inclinación que sentía hacia el indígena, o tal vez a influencias masónicas contrapuestas por definición, a cuanto procediese del clero ${ }^{11}$.

10. El P. Mariano Gil se ganó las iras del Katipunan cuando esta secta se vio descubierta. De tal modo que en el museo de Agustinos se conserva la fotografia que de su retrato recibió por correo interior con una leyenda en tagalo que decia "iHoras mo na!", que vertida al español, resulta una terrible amenaza y quiere decir: iLlegó tu hora!

11. F. Almagro: "Historia politica de la España Contemporánea", 336. 
La duda y la incertidumbre tenían en constante alarma a los españoles, y cada cual por su cuenta buscaba en las fuentes oficiales las noticias que habían de darle tranquilidad. Entretanto, en el gobierno civil de Manila se desplegaba toda la actividad que corre parejas con la voluntad y el esfuerzo demostrado por el entonces gobernador D. Manuel Luengo y Prieto. Y empezaron a hacerse prisioneros, detenidos y condenados. Empezó a funcionar un juzgado especial contra los cabecillas Andrés Bonifacio, Pío Valenzuela, Alejandro Santiago, Faustino Villarruel, Aguedo del Rosario, Enrique Pacheco, los tres hermanos Luna Novicio y otros principales. Otra vez es F. Almagro el que se pregunta, al tiempo de narrar los primeros días de la insurrección de Filipinas: ¿Sería el general Blanco, no ciertamente un rayo de la guerra, quien resolviese, pronto y bien, el problema de que España no podía desentenderse en el triste otoño de $1896 ?^{12}$.

Parece ser que no. Es más : ese problema, tan vidrioso y grave, no tardaría en resolverse en contra del general, cada día en mayor entredicho. Las actuaciones del citado Juzgado especial contra parte de los cabecillas se tramitaban con patente rigor. Pero el general era acusado por los patriotas españoles, de aquende y allende del mar, de llevar las cosas con una apatía incomprensible ${ }^{13}$.

La guerra entretanto, había comenzado. El general Blanco, Marqués de Peña Plata, capitán general y gobernador de Filipinas, había dado un bando que, comenzaba con las siguientes palabras: "Los actos de rebelión realizados en estos días por algunos grupos de gente armada en diferentes puntos del territorio de esta provincia, turbando gravemente la tranquilidad pública, exigen la más severa y ejemplar represión, para ahogar en su germen tan criminal como descabellada intentona». Manila convirtióse en pocas horas en una mansión guerrera. Los mozos y los viejos, hábiles para mantener entre sus descarnadas manos un fusil o un sable, andaban presurosos en sus funciones de reclutas ${ }^{14}$.

12. Ibid. 341-342.

13. Hasta tal punto debió ser esto cierto que el Arzobispo de Manila. a la sazón el dominico P. Nozaleda, y los Provinciales de los distintos Institutos religiosos residentes en Filipinas enviaron desde Hong-Kong una demanda que decía así: "Situación, agrávase. Rebelión, extiéndese. Apatía Blanco, inexplicable" (Cit. por F. ALMAGRo, 346).

14. El general Blanco, con ocasión de la creación del batallón de voluntarios, dirigió una brillante y patriótica alocución: "Voluntarios 
El pánico que reinaba en Manila era grande. La insurrección corrió como la pólvora. No solamente en Manila, Cavite y Nueva Ecija, se había iniciado el movimiento de insurrección, sino que también en Bulacán, Batangas, Mnong y La Laguna ardían por los cuatro costados. Y de este modo, lo que se tuvo por travesuras de muchacho, o por simples algaradas, llegó a comprender el general Blanco que era una formal revolución. Se procedió entonces al embargo de los bienes de los insurrectos y se dio un decreto y una larga instrucción para el fiel cumplimiento del mismo ${ }^{15}$.

El autor del "Katipunan» se siente molesto por este embargo de los bienes de los insurrectos. Lo cree ilegítimo y para él hubiera estado mejor la absoluta confiscación de todos ellos. La razón que alega es que con la confiscación se hubieran evitado ciertos abusos que en esta materia se dieron. Y cita por vía de ejemplo, el caso de haber nombrado a la esposa de Quico y Rojas administradora de los bienes embargados a este cabecilla de la insurrección, hecho que fue muy comentado en Manila.

Los voluntarios y el cuerpo de vigilancia prestan notorios servi-

-les decía-: acabáis de realizar el acto más grande y más trascendental de cuanto puede llevar a cabo un ciudadano armado: el juramento de su bandera, juramento sagrado y solemne, que imprime sobre el alma del que lo preste una huella que jamás se borra.

Cieito que todo español amante de su patria está obligado a defender la bandera nacional y que siente latir involuntariamente su pecho al contemplarla, pero esa noble sensación se extrema y sube de punto cuando esa bandera es la propia, la que, jurada después de bendecida, se convierte en enseña venerada del cuerpo a que colectivamente pertenece, en el que instantáneamente se despierta hacia ella el amor más vehemente, que lleva hasta el sacrificio a los que bajo sus pliegues se cobijan y convierte en héroes hasta morir en su defensa a quienes fueron momentos antes tranquilos y pacíficos ciudadanos.

Seguro estoy de que todos, presa todavía de emoción tan noble, os sentís llenos de entusiasmo, hacia vuestra preciosa enseña, y que deseáis en el fondo de vuestros pechos ocasiones en que combatir y vencer para coronarla con el laurel de la victoria, que no dudo obtendréis si llegara el caso de poner a prueba vuestro valor y firmeza, contando siempre para defender esa bandera y ese estandarte y morir antes que por nadie sean holladas, con un voluntario más en vuestro general en jefe (Cit. por Manuel Sastrón: "Insurrección en Filipinas", pág, 73-74.

15. Por ser muchos y demasiado extensos, no copiamos los decretos y ordenanzas que se expidieron en estos dias. La instrucción aludida consta de cuatro capítulos, con un total de 39 artículos más una disposición flnal. La fecha de la misma es la del 25 de septiembre de 1896. Puede consultarse el apéndice de este mismo trabajo y otros del Archivo de Agustinos Filipinos de Valladolid. 
cios a la causa española, en sus pesquisas, detenciones y hallazgos de documentos que comprometían a muchos insurrectos ${ }^{16}$.

Por el mes de Octubre se creyó que la insurrección estaba dominada. "El grave suceso, que ha tenido realización en algunas de estas provincias - leemos en la famosa circular publicada en «El Español»- durante tres días seguidos ${ }^{17}$ de haberse levantado en armas contra nuestras instituciones, muchedumbres ilusas, puede ya considerarse como dominado, pues el movimiento insurrecional se halla actualmente en muy corta extensión localizado».

Pero es curioso observar cómo, cuando esta circular se publicaba, toda la provincia de Cavite estaba levantada en armas, llegando hasta Las Piñas, casi a las puertas de Manila ${ }^{18}$.

La opinión española pedía las cabezas de los verdaderos culpables; quería castigar con brevedad, la ofensa que a España le habían inferido los cobardes enemigos que usaban de traiciones y de emboscadas miserables como principios esenciales de la revolución. Pedían las cabezas de los personajes que todas sus grandezas y sus prestigios los habían recibido de la magnánima nación española y que de modo tan criminal pagaban sus atenciones y sus cuidados ${ }^{19}$.

Parece ser que los rebeldes esperaban la protección del Japón pa-

16. En el barrio de Trozo, perteneciente al distrito municipal de Binondo, el capitán de voluntarios $D$. Carlos Marcos halló una caja de zinc que, enterrada a cinco metros de profundidad, contenía documentos y actas importantes, atiibutos masónicos, entre ellos un horrible mandil, y muchos otros papeles pertenecientes al Katipunan. Dichos documentos y atributos masónicos los hemos visto repetidas veces en el Museo de los Agusinos de Valladolid, pues durante muchos años estuvieron a la vista del publicc. Hoy están guaraados for medidas de prudencia y díscreción.

17. En la Biblioteca del Colezio Seminario de PP. Agustinos Filipincs de valladclid se halla una hermosa colección de recortes de periódicos la cual fo: ma varios volúmenes que el benemérito agustino P. Eduardo Navarro fue reuniendo durante estos años de revolución y los posteriores de la suerra de España con Estados Unidos. Ello ofrece un material de primera mano para los sucesos que nos ocupan.

18. El Capitán General, D. Ramón Blanco y Erenas, se había hecho ilusiones de que la revolución estaba sofocada. Prueba de ello es el bando dado en Manila el día 25 de Octubre del año citado en el que decía lo siguiente: "Resuelto a mantener con firmeza el imperio de las leyes, utilizando todos los medios que las mismas me confieren para restablecer la paz pública, alterada por unos cuantos malvados que en breve sufrirán el castigo correspondiente a sus crímenes... etc. A continuación ordenaba y mandaba pasar por las armas a todos los culpables de traición.

19. "El katipunan", 22. 
ra el logro de sus fines, aunque fuera a costa de un servilismo peor que hasta el que entonces habían soportado. Los actos de horror y de violencia se sucedieron sin interrupción y muchos hombres de bien, saglares y religiosos, fueron pasando por las armas. Sobre todo, en Joló fue terrible la acción de los filibusteros. De Joló llegaban noticias alarmantes, y de otra posible sublevación, de carácter filibustero, por lo que trataban de sorprender a todos los españoles residentes en la plaza y degollarlos sin compasión alguna ${ }^{20}$.

Faltan hombres que resistan el empuje de los insurrectos. La situación se hace por horas desesperante. La solución está en los refuerzos que deben llegar de España. Aguinaldo es generalísimo de las fuerzas sublevadas en Cavite. Buen estratega e inteligente conocedor de su pueblo, sabe aprovechar lo que hoy llamamos «la quinta columna) para sus fines de independencia total. Los manifiestos que dirigía a los sublevados eran llevados a Manila y otras importantes ciudades por los espías que tenían bien pagados. Con todo, hemos de decir que también se dieron, durante la sublevación, casos verdaderamente heróicos entre tagalos y españoles. Los soldados de España hicieron proezas de gran valor y el nombre del general Azcárraga corrió de boca en boca con la aureola de los grandes y eminentes patricios.

El periodista Antonio Navarro decía una vez: “Es imposible relatar los rasgos de valor y heroísmo que he presenciado, pues la emoción que siento, la molestia que me produce mi herida de la manoy el cansancio que me agobia, no me permiten escribir ni coordinar ideas. Una oración y una lágrima para los nuestros, y un entusiasta aplauso para los que viven" ${ }^{21}$.

20. El cronista habla de los estragos cometidos en otras provincias $y$ de los planes maquiavélicos proyectados en Joló, que fueron descublerLos por fortuna $y$, de este modo, abortada también la sublevación.

21. Sastron: "Insurrección en Filipinas", pág. 148. A propósito de este periodista es de toda justicia destacar su comportamiento durante las sangrientas jornadas de Benicayan. Antonio Navarro - se nos dice- es todo un héroe, que no tiene la cruz laureada, no porque no se la haya merecido, sino porque es sólo patrimonio honroso de los cuerpos del ejército; pero tiene otra cruz que es el agradecimiento de cuantas personas fueron asistidas por él en el mismo campo de batalla, pues el joven periodistas, confundido con las tropas de primera línea, coronó las trincheras deì enemigo de Benicayan y de ellas rêcogió el' cađáver del capitán Guarido. En sus brazos expiró el bravo teniente Castro, al que prestó un gran servicio en los momentos de su agonía, cual fue escribirle una carta para el coronel Marina, en la que le notificaba cómo dejaba un 
El general Blanco fue sustituido en el mando por el general Polavieja. Desembarcado éste en Manila el 2 de diciembre del mismo año I 896 tenía ante sí el mismo problema que había tenido el general Weyler en Cuba como sustituto de Martínez Campos; y tenía que ser Cánovas el encargado de resolver la ardua y difícil papeleta de los nuevos nombramientos.

A Polavieja, en Filipinas, no le quedaba otro recurso que al de Weyler en la "Perla de las Antillas": llevar la guerra con todo rigor. Además, le tocó al "general cristiano», como era llamado en la corte de Madrid, la ingrata función de sustanciar los procesos incoados en tiompo del general Blanco, a los que, naturalmente había que añadir los que se iniciaran bajo su mando, en gran número, porque las conspiraciones seguían en aumento. Polavieja, en fin, fue el que se vió obligado a firmar la sentencia contra Rizal el día 28 del citado mes ${ }^{22}$.

El general Polavieja disponía de zo.ooo hombres, suficientes en un principio, al menos para llevar a cabo la ofensiva en Cavite y defender el resto de la isla de Luzón. Con el fin de localizar la insurrección en el punto más peligroso - Cavite- Polavieja lleva a cabo una serie de operaciones previas que dieron excelente resultado, causando muy pocas bajas al ejército español. Luego se lanzó a la gran ofensiva bien secundado por sus generales, y consiguiendo una tras otra resonantes victorias.

Pero Polavieja que se daba perfecta cuenta de la importancia que tenía el dominar por completo la insurrección en todas las islas, no era escuchado en la Metrópoli; le regatean y aun le niegan los refuerzos que necesitaba y reiterademente solicitaba. Las fuerzas peninsulares no eran, ni con mucho, bastantes para acudir a todos los puntos

hijo natural en España y que ponía bajo su protección. Enterado de ello el capitán Sulriguet, de Estado Mayor, envió al periodista al lado del moribundo con el siguiente mensaje: "Corra y dígale que yo poseo bienes de fortuna y no tengo hijos, por lo que adopto el suyo que es mío desde hoy".

22. Parece ser que cuando Rizal escuchó la sentencia de muerte dijo: "es injusta". Luego, ya en capilla, asistido por padres de la Compañia de Jesús, firmó su retractación de los errores padecidos y contrajo matrimonio "in artículo mortis" con su amante, la irlandesa Josefina Bracke. Se cuenta que le causó una tremenda imprensión la imagen de Jesucristo, tallada por él mismo cuando era colegial y que habian llevado ahora a la capilla del reo. Recibió los sacramentos y murió reconciliado con la Iglesia en la histórica mañana del 30 de diciembre. 
donde su presencia era necesaria. Hasta los más optimistas vislumbraban en lontananza nubes anunciadoras de grandes infortunios. Las risueñas esperanzas, el rumor de imaginarios triunfos, conseguidos por nuestras armas íbanse poco a poco - dice un prisionero del Katipunan- disipándose como tenues espirales de humomo ${ }^{23}$.

Los misioneros nos contarán cómo se iban rindiendo, uno a uno, los pueblos de su jurisdicción y desvelos. El autor de las "Memorias de un cautiverio) nos narra, con pluma elegíaca y grandilocuente a la vez, la pérdida de Ciparri, defendido con solo cuarenta fusiles españoles: "Quisiera que mi pluma tuviese el don de trasladar al papel, de encarnar en palabras y en ideas lo angustioso de aquella noche infausta, pasada la cual, habíamos de ver entrar en el pueblo al ejército revolucionario. La cabeza ardía hecha un volcán de pensamientos desgarradores ${ }^{24}$.

El general Polavieja, contrariado y enfermo, había dimitido con harto dolor de las tropas españolas, que veían en él al hombre capaz y único de llevarlas a la victoria final y definitiva ${ }^{25}$.

Era innegable que la desavenencia con el gobierno motivó la dimisión del inteligente y bravo militar; pero su malestar físico, que arrastraba desde la campaña de Cuba, hacía difícil su continuación en la capitanía general de Filipinas.

El cambio de mando tampoco resolvió entonces el problema; porque si el general Primo de Rivera, sustituto de Polavieja, logró sin grandes esfuerzos echar de Cavite a los partidarios de Aguinaldo, no pudo o no supo impedir que la rebelión se extendiese e infectase provincias como las de Nueva Ecija y Bulacán que descansaban tranquilas al lado de la legalidad y del orden.

El primer marqués de Estella, don Fernando Primo de Rivera, desembarca en Manila el 23 de Abril de 1897 . Como es fácil presuponer, las cosas habían cambiado bastante y tanto "las realidades polí-

23. G. Martinez, "Memorias de un cautiverio", (Manila, 1900), 1.

24. Ibid, 48.

25. Para más detalles de la insurrección y de las operaciones militares llevadas a cabo por el general Polavieja junto con el ejemplar despacho que envió a Madrid, dando cuenta de su enfermedad y de su último esfuerzo "por la patria y por el rey", puede consultarse Fernández Almagro: "Historia política de la España Contemporánea", págs. 335-365. 
ticas, como militares, si cabe este distingo en tiempo de guerra, eran muy diferentes a las que su antecesor Polavieja hubo de afrontar no más que cuatro meses antes ${ }^{26}$.

Las alocuciones rituales del nuevo capitán general "a los habitantes de las Islas Filipinas", ", y "a los Ejércitos de mar y tierra», y (a los voluntarios) manifestaban un optimismo que contrastaba con el pesimismo no fingido de los despachos oficiales a Madrid. Primo de Rivera debía proseguir la ofensiva contra la provincia de Cavite, ocupada cn casi tcda su extensión.

Y la campaña de Cavite terminó favorablemente para las tropas españolas. Primo de Rivera trata ahora de completar el triunfo militar con el político; para lo cual concede un indulto amplísimo, de resultado dudoso, pues si es verdad que muchos rebeldes se presentaron pidiendo perdón, fueron muy pocas las armas que entregaron.

Pero ni Manila, en relativa calma, ni Cavite, pacificada, eran toda la isla de Luzón. Aguinaldo, huido, se hizo fuerte en los montes de Puray, al Norte de Manila, y la insurrección cobró nueva vida en las provincias de Bulacán, Nueva Ecija y Pampanga. "En los montes de Arayat estaba la llave que permitiría la posesión de aquellas tres provincias, y en la ocupación de Biac-na-bató, residencia del gobierno rebslde, estribaba el interés de las operaciones que el general en jefe proyectaba para junio y julio» ${ }^{27}$.

En favor del general Primo de Rivera tenemos que anotar ahora sin retractarnos del juicio que dimos sobre él en capítulos anteriores, cómo él, mejor tal vez que ninguno de sus antecesores, concibió la idea de utilizar a los indígenas y encuadrarlos dentro de las filas de las tropas españolas, para asegurar, de este modo, la fidelidad, aunque tal vez pecara de excesiva confianza en el indio y en la mixtura de este soldado con el español. No carece de visión y es digna de tenerse en cuenta la frase del general: "Sin la lealtad del indio pierde España el Archipiélago... Tal vez una excelente y bien organizada política, y la restricción en leyes que tanto han influido en las condiciones y carácter del indio, que han hecho de un ser sumiso, respetuoso y humilde, obediente y satisfecho, un hombre díscolo, con aspiraciones locas, va-

26. F. Almagro, o. c. 358.

27. Ibid, 362 
no y conspirador, pudieran ir obrando de tal suerte que, poco a poco pəro siempre muy lentamente se pudiera ir disminuyendo el contigente peninsular) ${ }^{28}$.

Primo de Rivera entendía que la insurrección estaba sofocada, sin que desapareciera el peligro de nuevos levantamientos, a poco que se descuidase el mando, por las singularidades del indígena. Pero, al mismo tiempo, era necesario evitar la prolongación de la guerra, con su doble sangría de hombres y dinero, y prever un acuerdo con el enemigo. Al general le preocupaba la acción de los filibusteros, que desde Yokohama, Shanghay, Hong-Kong y Singapur acechaban toda acción de evitar el juego de la guerra. El general en jefe pensó primeramente en el soborno, valiéndose de Don Pedro A. Paterno, personalidad filipina de alto relieve, "hombre de buena fe", a juicio del mismo Primo de Rivera, el cual pedía la suma de 700.000 pesos para el logro de sus fines. Pensó también en la guerra sin cuartel, llevada hasta sus últimas consecuencias, pero siempre y aún con la victoria por parte de los españoles de dudoso resultado, y siendo necesario para la paz la intervención directa del ejército indígena, principalmente tagalo.

Prevaleció el proyecto primero, que iba a dar como resultado la famosa paz o "Pacto de Biac-na-bató». El gobierno de Madrid autorizó al capitán general para que firmase el acuerdo. Aguinaldo, por su parte, envió a Primo de Rivera el acta de sumisión, en la que se reconocía la soberanía de España a cambio de ser concedido a los insurrectos el perdón y el olvido de su conducta pasada y barcos que les condujeran a Hong-Kong. El día 23 de diciembre de 1897 llegaron al campamento de Aguinaldo los comisionados españoles bajo la presidencia del teniente coronel de Infantería don Miguel Primo de Rivera. Hubo el banquete de rigor y los brindis «por la paz y la felicidad de la tierra filipina, por el invicto Ejército español, por el Rey, por la Reina Regente y por el general Fernando Primo de Rivera, pacificador de las Islas Filipinas».

Lo que siguió después es de todos conocido: "El pacto de Biacna-batón,, así llamado por ser ésta la sede del gobierno de Aguinaldo, el cual embarcó para Hong-Kong con los principales colaboradores de

28. Ibid. 363 . 
insurrección, con lo cual todos pensaron que la guerra había terminado.

Todos, hasta los más pesimistas, podian darse por satisfechos. Al general Primo de Rivera se le concedió la Gran Cruz Laureada de San Fernando; en la catedral de Manila se cantó un solemne ite. deum" de acción de gracias; la prensa y los cablegramas enviados a Madrid no daban lugar a pczer en tela de juicio la pacificación del Archipiélago de Magallanes.

Dupuy de Lome, representante de España cerca del gobierno de Estados Unidos podía enviar al Ministro de Estado el siguiente telegrama: "Mi opinión general sacada de mis conversaciones y observaciones es que nunca ha sido tan buena la situación política ni tan fácil mi misión desde Mayo de I895. Según se me ha manifestado, han desaparecido todos los motivos de irritaciones» ${ }^{29}$. ¿Falta de visión política? ¿Ingenuidad? ¿Torpeza?... De todo pudo existir en aquella hora. Lo que nadie pone ya en duda es que aquella (arriesgadísima confianza)" se vendría pronto abajo con las terribles y tristes realidades del i 898 . Consideramos mucho más equilibrados y objetivos a los historiadores que a los escritores religiosos que se ocuparon del suceso. Incluso creemos que su juicio es mucho más exacto que el que nos dan Sastrón, autor de la "Insurrección en Filipinas», y Castillo, autor de "El Katipunan». Con todo, creemos que también es interesante escuchar a estos últimos y oir lo que dicen sobre el famoso pacto de Biac-na-bató. E1 P. Joaquín Durán en sus «Episodios de la revolución filipina», moja su pluma en la tinta más negra cuando se pone a escribir esta página. “ Biac-na-bató! en tus escabrosidades y asperezas - dice- quedó enredada y maltrecha la honra española : en tus tenebrosos antros forjóse el rayo desolador que troncó el arbol gigantesco de la dominación hispana; en tus ennegrecidos horizontes fraguóse la tempestad horrenda que desmanteló y echó por tierra al ciclópeo alcázar de nuestras glorias) ${ }^{30}$.

E1 tono no puede ser ni más polémico ni más engolado; pero, aún con todo lo tópico que se quiera, no deja de ser un testimonio de un testigo de quien vivió aquellas horas difíciles para Filipinas y para España.

29. Ibid. 449

30. J. Duran, "Episodios de la revolución filipina", 16. 
"Biacnabató» -en lengua tagala: "piedra abierta», tajada, o partida - lugar donde se desarrollaron los acuerdos de paz entre Primo de Rivera y Aguinaldo, Biacnabató fue el período agónico -el párrafo pertenece ahora a Manuel Sastrón- de la insurrección filipina; una hipócrita truhanería de algunos indígenas; un grave error de los gobiernos de la Metrópoli; el mayor quebranto de la dominación española en el Archipiélago de Legazpi»" ${ }^{31}$.

Tampoco esto se puede decir. La intención del historiador de la insurrección filipina es loable, pero el juicio que da sobre aquella paz y las explicaciones a la misma pecan de inexactas. Los motivos son muy otros y ya los ha visto el lector. Como colofón nos vendrá a decir después: A las 48 horas de haberse encargado del mando el general Augusto, embarcó en viaje de regreso a la Madre patria el Sr. Marqués de Estella... ¡En qué oportunidad marchó! ¡Hasta qué punto hubiera llegado su amarga decepción viendo regresar al Archipiélago a las cinco o seis semanas a Emilio Aguinaldo, ya precedido de otros de los cabecillas de Biacnabató!

Es cierto; pero el mismo Sastrón, que no parece sentir ninguna simpatía por el general Primo de Rivera, reconoce que la paz de Biac-na-bató fue una imposición del gobierno de Madrid, en lo cual no anda del todo descaminado. Por otra parte, podríamos preguntar: ¿qué cabía hacer en aquel momento? ¿cuál era lo mejor para el porvenir de España en sus colonias? ¿Hubieran acertado estos polemistas y exaltados patriotas en la solución del problema? Mucho nos tememos que no.

Otro tanto podríamos decir al P. José Rodríguez de Prada - prisionero del Katipunan- cuando escribe: España ha sido engañada por españoles degenerados, sin conciencia y sin dignidad. Las naciones envidiosas de sus tradicionales glorias la tendieron el lazo en que incautamente cayó envuelta perdiendo para siempre su honor y los laureles que hermoseaban su corona ganados en cien combates) ${ }^{32}$.

Lo que nadie puede negar, y esto tal vez no lo hayan recalcado lo suficiente los historiadores, es que apenas volvieron los rebeldes a

31. Sastron, o. c. 311-325.

32. J. RODRIGUEz DE PRADA, "Memorias de un prisionero", (Madrid, 1901) 3. Por lo regular el misionero que se encontraba de cura párroco en un distrito importante, al ocurrir el momento de la insurrección, se apresuró a dar cuenta a su superior mayor de todo lo acontecido alli. Esto hace 
sus hogares consideraron la paz como un acto de debilidad por parte de los españoles y hasta se atrevieron a mentir descaradamente diciendo incluso que habian hecho correr a los soldados de España, cuando, en realidad, los vencidos en todos los frentes habían sido los insurrectos. Pero esto también es explicable y más cuando se piensa en los hechos que van a ocurrir después.

que nuestro trabajo se avalore con la sencillez y espontaneidad con que los profesionales narran los tristes sucesos de la insurrección filipina. A los autores arriba citados, ienemos que añadir las cartas extensas del $P$. Rufino Santos que hemos leído enteras; las que escribió uno de nuestros religiosos a Mariano Llanera; la que el provio Llanera escribió desde Biacnabató al P. Victoriano Andrés; la "memoria del tiempo de la insurrección tagala", cuyo autor se oc'slta en el pseudónimo de Anser el cual, por el estilo y por los hechos qu' narra, bien puede ser el P. Joaquín D. Durán; la interesante relación que escribe el $\mathbf{P}$. José Laviana sobre lo ocurriao y presenciado por él en Almcdián; varias cartas cruzadas entre el general Aguinaldo $\mathrm{y}$ el superior de los jesuitas en Filipinas; una carta del cabecilla Deodato Arellano dirigida al Gobernador General desde la prisión; el alegato y pregón que dirige Andrés Bonifacio incitando a la rebelión y otras cartas de los misioneros al M.R.P. Provincial Manuel Gutiérrez. Todas ellas se conservan en el Archivo de Agustinos Filipinos de Valladolid, y todas ellas han sido revisadas y seleccionadas por el que esto escribe. A los hechos conocidos y a la interpretación de los hechos por los autores que hemos manejado y citamos en la bibliografia, los misioneros agustinos añaden el testimonio inmediato, el juicio persona1, la pequeña anécdota; en ocasiones, el juicio acertado. 
b) La guerra con los Estados Unidos

No intentamos en este capítulo estudiar la guerra, como tal, que hubo de mantener España con los Estados Unidos, sino más bien sus perfiles fundamentales, sus momentos culminantes y sus consecuencias fatales para nuestra patria, con el fin de que ellos nos lleven como de la mano a los hechos y perfiles religiosos y centrar el estudio posterior de la persecución religiosa.

La cuestión de Cuba y Filipinas, sobre todo la primera, con respecto a Estados Unidos, venía ya de bastante atrás. En el año I $854 \mathrm{Mr}$. Soulé, ministro plenipotenciario de esta nación en Madrid, ante ciertas medidas por parte del Capitán General de Cuba que afectaban a la raza negra existente en la Isla, declaró que su nación no consentiría que se llevase a cabo los designios de "africanizar» Cuba, según se rumoreaba. E hizo ver cómo España no debía esperar de Francia e Inglaterra los auxilios necesarios para asegurar la posesión de la isla, sino que debía unirse a la "Confederación" apoyándose en los robustos hombros de los Estados Unidos '.

Los primeros roces con Norteamérica ocurrieron ya por este mismo tiempo y siendo Presidente del gobierno español el Conde de San Luis. Uno de ellos fue el incidente "Black Warrior", barco americano, que fue a atracar en la Habana «en lastre», siendo así que llevaba a bordo 957 pacas de algodón. Poco más tarde tiene lugar un caso semejante con el barco "El Dorado», sospechoso de trabajar con los filibusteros que estaban organizando expediciones para Cuba en los Estados Unidos.

Para evitar más serias cuestiones, se enviaron instrucciones al cónsul español en Washington con el fin de que se entendiese con el gobierno federal sobre el límite de las jurisdiccionales, recomendándole que procurara quedasen a salvo nuestros intereses en aquellas latitudes $^{2}$.

Asi las cosas, podemos preguntarnos ahora: ¿Cómo y por qué los españoles fuimos a la guerra? El ilustre historiador Pabón se hace

1. J, BECKER, "Historia de las Relaciones Exteriores de España aurante el siglo XIX", Imprenta Vda. e Hijos de Jaime Retés (Madrid,. 1924). II. ${ }^{\circ}$ 300.

2. Ibid. 338-339. 
la pregunta de otro modo: ¿cómo y por qué los españoles creyeron firmemente en la victoria de España sobre los Estados Unidos, o más concretamente, en la derrota de la marina norteamericana por la escuadra española ? $^{3}$ ¿Cómo se fue a la guerra?

Ha de historiarse para ello puntualmente el duelo diplomático de España con los Estados Unidos en las gestiones españolas de Cánovas y Sagasta, y en las presidencias norteamericanas de Cleveland y Mac Kinley. Ha de estudiarse en fin, el marco internacional, el cuadro exterior en que el 98 tiene lugar. Por último, debe aludirse a los motivos de opinión de los intelectuales del "Desastre" buscaron su razón última en la esencia de España. Pero el 98 fue indudablemente un acontecimiento en la existencia del mundo contemporáneo, en el curso de una historia internacional que condicionaba la suerte de España y de sus últimas posesiones ultramarinas.

García Escudero, en su libro: "De Cánovas a la República”, dejará escrita esta frase que se nos antoja demasiado tajante: "no el pueblo ni la Monarquía : la clase gobernante era la responsable»" ". El ministro norteamericano en Madrid, Woodford, piensa que los dirigentes españoles fueron a la guerra empujados por la creencia de que, evitarla, cediendo en el pleito cubano, acarrearía una revolución interna ${ }^{5}$. La explicación que da Sagasta es otra: "Estábamos ante un terrible dilema: o la guerra con todas sus consecuencias, o el deshonor) ${ }^{6}$.

El inteligente Canaleja sabía muy bien que ir a la guerra con Estados Unidos era una quimera; y asi se lo hizo ver al jefe del gobierno, que en estos momentos era Sagasta: Tienen los Etados Unidos - le dijo - una verdadera escuadra con cuatro acorazados de primera, muy superiores a las nuestras, y muy superiores también en número y calidad los demás acorazados con que cuentan ?.

Fernández Almagro, al que vamos a seguir más de cerca que a Manuel Sastrón y otros cronistas empeñados en llevar su narración de un modo parcial y demasiado apologético, como ocurre en los religio-

\footnotetext{
3. Pabon, "Cambó", 169.

4. Ibid. 170.

5. STUART L. Woodford: "The American Spanisch War" (Norwich 1899) 9.

6. Cit. por Pabon en "Cambó", 172.

7. ROMANONES: "Sagasta", 193.
} 
sos agustinos que ya conocemos, tiene una frase lapidaria: Sin piedra ni honda, no podía David vencer a Goliat)s ".

Pero la colosal mentira creció y se mantuvo incólume sobre una fe y un sentimiento sagrados. Seguía la sombra de Cánovas para quien Cuba era una provincia española. Se trataba, pues, de nuestro propio territorio, de nuestro propio territorio nacional, en expresión de Leonor Meléndez ${ }^{9}$.

¿Quién pudo, entonces, dar alas a tan equivocada convicción patriótica? $\mathrm{Pi}$ y Margall no anduvo con rodeos en declararlo: La prensa, "una prensa infame), fue la causante principal de que España, el pueblo español, enardecido y patriota, se lanzara a una guerra suicida. Los hombres sensatos no la querían; pero a la prensa le interesaba ahora airear los motivos patrios y el valor del soldado español ("para conseguir sus ignorados fines) y los consiguió para desgracia de nuestro sufrido pueblo ${ }^{10}$.

El hitoriador de la Regencia Gabriel Maura y Gamazo, nos habla, a este propósito, de cla insensatez de la prensa periódica, que en su casi totalidad azuzaba a sus lectores a pedir la procaz inverecundia de la nación norteamericana a quien suponía insignificante y casi impotente) ${ }^{11}$.

Fue una prensa que funcionó como un mecanismo al servicio de una consigna, esencialmente falsa, porque aparenta representar una opinión cuando la está creando en la mentira.

Todos sabían que la guerra se iba a ventilar en el mar, y que la escuadra del almirante Montejo que comandaba el acorazado (María Cristina» no podría hacer nada ante la poderosa del almirante norteamericano Dewey. Todos sabían que en aquel combate naval, tanto en Cuba, donde contábamos con una fuerza superior a la de Filipinas, y con el almirante Cervera como jefe de la escuadra, como en Filipinas, tendría que ocurrir lo que proféticamente había anunciado Montejo al tiempo de hacerse a la mar hacia Subic: que aquello ter-

\footnotetext{
8. Fernandez Aumagro: "En torno al 98" (Madrid 1948) 32.

9. LeONOR Meléndez. "Cánovas y la politica exterior española", (Madrid 1944) 337.

10. Cit. por Pabon, en "Cambó", 173.

11. Maura y Gamazo, "Historia critica del reinado de Alfonso $X I I I$ durante su minoridad" (Madrid 1944) 337.
} 
minaría en un desastre y no sin ejemplo entre los españoles para que tuviésemos menos justificación.

Manuel Sastrón, el historiador de la insurrección de Filipinas, se pregunta : ¿quién cometió torpezas?... Y responde: “Las hubo, sí;

y grandes; pero las cometieron, en primer término, los presupuestos de la paz que mantenían en el deplorable estado que hemos visto nuestros barcos. Los cometieron, en segundo término, los tan recomendados economistas, que venían a privarlos del personal correspondiente y del material indispensable... Hubo torpezas, sí; pero fueron, es preciso decirlo, más de allende que de aquende. Las cometieron singularmente aquellos ministros de la Corona, quienes no acertaron a ver la nueva fase que venía tomando el pueblo filipino...; las cometieron en el Archipiélago aquellos gobiernos que, menospreciando las voces de la experiencia, adoptaron la política de un inverosimil "statu quo", que ni fueron al vado ni a la fuentes ${ }^{12}$.

La guerra de España con los Estados Unidos se desencadenó en la hora prevista, ni antes ni después; sencillamente cuando el gobierno de Madrid no pudo hacer otra cosa que aceptar el desafío del de Washington. La guerra, al fin y a la postre, no fue otra cosa que el desen. lace total del duelo, diplomático y público, hispanoamericano. Las palabras del eminente historiador Jesús Pabón son harto claras y significativas : "El diálogo confidencial - a proposito de la venta de la Isla que proponía el gobierno de los Estados Unidos-- se soterró, fracasado, en el silencio de quienes participaron en él. Es explicable que los actores españoles no registrasen su intervención en aquello que la conciencia juzgaba una traición o una vergiienza. Para el historiador resulta bastante difícil encontrar la huella de lo hecho y de lo padecido por quienes vivieron por entero la tragedia, es decir, por quienes conocieron la existencia de una solución pacífica y hubieron de prescindir de ella y de presidir el desastres ${ }^{13}$.

Letra a letra, golpe tras golpe -escribe F. Almagro- caía el texto de la (resolución conjunta) como terrible serie de mazazos sobre la nuca de un pueblo cuyos órganos responsables habían hecho ciertamente todo lo posible para evitar la ruptura de relaciones ${ }^{14}$. Cua-

12. Sastron, ob. cit. 396-397.

13. PABon, "El 98, acontecimiento internacional" (Madrid 1952),

14. El autor se refiere a la "joint resolution", aprobada por el Congreso de Estados Unidos y firmada por el presidénte Mac Kinley, donde 
lesquiera fuesen las lejanas y reiteradas culpas anteriores, el Gobierno español no pudo proceder con mayor corrección, prudencia, cordura y dignidad. Hizo todas las concesiones que los Estados Unidos sucesivamente hubieron de exigir. ¿Concesiones tardías, si se tiene en cuenta el tiempo perdido a contar del fracaso de las reformas de Maura?... Fernández Almagro contesta: "Probablemente, sí. Pero nunca era demasiado tarde para evitar el choque bélico con una nación como España que manifestaba una sincera y terminante voluntad de acuerdos) ${ }^{15}$.

Pero en las históricas jornadas de Abril de 1898 ya no cabía hacer otra cosa que ir a la guerra. Los que en modo alguno la querían se vieron obligados a aceptarla como hecho consumado; y los que la venían ansiando, "muy a la española), ya la tenían. Callaron entonces los pacificistas a ultranza; y los poetas cantaron a la España del Cid y Pelayo y de Lepanto ; pero, como apunta atinadamente el autor últimamente citado, la Bolsa tiene una sensibilidad distinta, atenta a otros estímulos, y acusó un extraordinario pánico en el mismo día y hora en que el pueblo vitoreaba a España, a la Reina Regente y al Rey-Niño.

Era el 20 de Abril de 1898 . Aquel día habría apertura de Cortes y María Cristina leería el "mensaje de la Corona». La guerra estaba ya en marcha, de hecho y de derecho. Y no sólo en Cuba y Puerto Rico, sino también en Filipinas, teatro igualmente previsto, desde que el fracaso de la paz de Biac-na-bató, se había hecho patente con el ataque de Bolinao, que determinó violentísimo combate; y con el levantamiento general de los poblados al Norte de Zambales. Era indudable que Aguinaldo, desde la ciudad de Hong-Kong -y aquí sí que estamos totalmente de acuerdo con los autores Sastrón y Castilld y demás apologistas de la tragedia - estaba en inteligencia y contacto con los Estados Unidos; y que este poderoso pueblo estaba dispuesto a intervenir directa y activamente en el Archipiélago lo mismo que en Cuba.

A ello hay que añadir la falta de visión que sobre el poder de este pueblo tenía don Basilio Augustí, sucesor de Primo de Rivera en la

se pedia, entre otras cosas, que el pueblo cubano debia ser libre, exigiendo al Gobierno de Madrid la inmediata renuncia a su soberanía y autoridad sobre aquel pueblo. 493

15. F. Almagro: "Historia política de la España contemporánea", II." 
Capitanía general de Filipinas. Como tantos otros ingenuos españoles, subestimaba la potencia norteamericana y estaba firmemente persuadido de que el valor y arrojo de los soldados españoles bastaría para ganar la guerra. Y en este tono optimista se dirigió a los filipinos pronosticando que la lucha iba a ser breve y decisiva.

En lo de breve y decisiva decía mucha verdad; pero fallaba en la predicción del pueblo que se iba a levantar con el triunfo. El primer desengaño lo tendría el propio Augustí cuando viera cómo nuestra escuadra, comandada por el almirante Montejo, y compuesta de seis cruceros con un total de I I. $35^{\circ}$ toneladas, 34 cañones grandes y 26 pequeños, no todos en uso, iba a ser destrozada en aguas de Cavite por la más fuerte y mejor equipada de Norteamérica, que estaba a las órdenes del almirante Dewey, pues con sólo mantenerse a dos, o dos mil quinientas yardas, las naves españolas resultaban tan inofensivas como los blancos usuales en las prácticas de tiro.

El 30 de abril y a las ocho de la noche se dejaron ver las primeras luces y en ellas las primeras señales del enemigo a la vista. Los barcos españoles se pusieron en guardia. A la una de la madrugada se había roto el fuego. La escuadra americana, ya en el centro de la bahía, formó su línea de combate frente a Manila; la batería española de la Luneta le hizo fuego, y los buques enemigos, después de lanzar contra ella unos cuantos proyectiles, operó un movimiento con el fin de situarse frente a Cavite y atacar de lleno a la escuadra española, que se hallaba, por necesidad, a la defensiva y formando una línea curva de combate desde Punta Sangley hasta el nordeste del arsenal de Cavite ${ }^{16}$.

El acorazado "María Cristina» no abrió fuego hasta las cinco y media de la mañana, siguiéndole el resto de la escuadra. Uno de sus disparos alcanzó al (Baltimore» poniendo fuera de combate a cinco tripulantes. La escuadra americana atacó en seguida batiéndose en contramarcha y formando círculo frente a la española. El objetivo principal de la escuadra americana era destruir el "María Cristina», buque insignia español, y contra él dirigieron incontables disparos de cañón - 200 disparos por minuto- hasta hacer blanco, producir un incendio espantoso a bordo y dejarlo en seguida fuera de combate, teniendo que lanzarse al agua su tripulación para salvar la vida. Eran las

16. M. SASTRon: "Insurrección en las islas Filipinas", 387 ss. 
siete de la mañana del primer día de mayo de ${ }_{1} 898^{17}$. Después del "María Cristina" le tocó el turno al D. Juan de Austria»; y después al "Castilla"; y al "Ulloa»; y al "Isla de Cuba» y al "Isla de Luzón... A las ocho y media de la mañana todo estaba terminado. Trescientos cincuenta y seis marinos fueron las bajas que sufrió nuestra escuadra que quedó totalmente deshecha. Y los barcos que aún flotaban fueron hundidos del todo, no por orden del almirante Montejo "para evitar cayesen en poder del enemigo", como quiere Manuel Sastrón, sino porque así lo había ordenado el almirante Dewey, al tiempo de izar bandera blanca los españoles del fuerte de Santiago ${ }^{18}$, concediendo también la evacuación de las mujeres y de los niños, pero exigiendo una vez más que las baterías de la costa apagasen sus fuegos.

Entregado el arsenal de Cavite a los americanos por el comandante de la plaza, general Sostoa, las turbas tagalas que pululaban en torno a aquel establecimiento naval, no ocultando sus propósitos de ejecutar el bandolerismo y el pillaje, lo invadieron antes de que los nuevos dueños tomaran posesión de sus destrozados muros.

Otro tanto ocurrió con la ciudad de Cavite, abandonada de antemano por los españoles. Unos 500 ó 600 tagalos, armados de fusiles, cayeron sobre la plaza cometiendo en ella el saqueo que se puede imaginar. Las familias que, por su condición de indígenas o por parentesco con los naturales filipinos, pensaron no les iba a ocurrir nada y decidieron quedarse en la ciudad, sufrieron ahora vejaciones y atropellos indescriptibles. Varios religiosos salvaron sus vidas huyendo al hospital y fingiéndose enfermos y heridos, de modo que cuando llegaron los rebeldes no pudieron reconocerlos por tèner el cuerpo lleno de vendajes y aparentar estar mal heridos.

La ciudad de Manila se encontraba ahora en grave peligro. El

17. Un hecho digno de mención a bordo del "María Cristina" es el que se refiere al capellán del barco, Rvdo. Sr. Novo -así le llama el cronista-, el cual, herido gravemente y fracturadas sus dos piernas, se arrastraba como podía por cubierta confesando, dando la absolución y prestando los últimos auxilios a los heroicos marinos, hasta que una granada enemiga le dio en medio del pecho y destrozó todo su cuerpo (Cit. por SAstron, 390).

18. Sastrón, en su afán de quitar lastre, y de paliar la derrota, comete bastantes errores como el apuntado. Nadie duda del heroísmo y bravura de nuestros soldados y de que no habia naua qüe hâcer frente a la poderosa escuadra americana; pero los hechos deben contarse como fueron y de un modo más objetivo a como él lo hace en su historia de la insurrección filipina. (Vd. SASTRoN, 392). 
movimiento insurreccional recobró nueva vida y avanzó hacia la capital de Legazpi. El día 24 de mayo los tagalos entraron a sangre y fuego en el poblado de Santo Tomás; y el 25 desembarcaba en Cavite el generalísimo de las tropas filipinas, Aguinaldo, en compañía de otros I 4 jefes $y$ oficiales de las fuerzas rendidas en Biac-na-bató, procedentes todos ellos de Hong-Kong, y que habían hecho el viaje de regreso en un barco norteamericano, el "Ma Cilloch".

Estaba fallando hasta la idea del general Primo de Rivera, ya que algunos jefes indigenas que habían reiterado su adhesión a España, se pasaban ahora al ejército de Aguinaldo con unidades de soldados tagalos en pleno combate.

Esto, después de todo, se explica conociendo el carácter y la psicología del indio filipino. Lo que ya no se explica tan fácilmente es el abandono en que se encontraba la plaza de Manila por imprevisiones o errores de unos u otros, pero cuya responsabilidad mayor recaía sobre el general Augistí. Las quejas de personas religiosas y seglares son unánimes y todas ellas se preguntan doloridas: "¿qué se ha hecho durante el mes de mayo, funestísimo más que por los desastres de Cavite, por las inactividades del Capitán General, tranquilo, sin duda, porque los americanos no bombardeaban la ciudad? " ${ }^{19}$.

Y era la pura verdad. Transcurrían los días y la victoriosa escuadra americana no hacía ánimo de bombardear Manila, a pesar de que el almirante Dewey había exigido la rendición de la plaza y había aconsejado a los cónsules de distintas naciones residentes en ella que se pusiesen en seguida a salvo. En realidad lo que Dewey estaba esperando era el levantamiento general de los tagalos, la llegada de Aguinaldo a Cavite y la llegada también de nuevos refuerzos americanos. El optimismo de algunos españoles no tenía razón de ser.

Entre tanto, las columnas de Aguinaldo avanzaban hacia la ciudad operando en distintas direcciones. El general Augustí debió darse cuenta del grave peligro cuando vió que llegaban a la isla de Luzón cuerpos expedicionarios norteamericanos antes que los esperados refuer. zos españoles.

El pueblo de Manila vivía un penoso estado de incertidumbre. La ciudad estaba bloqueada y se ahogaba sin remedio de no llegar

19. Cit. por F. Almagro; 551. 
pronto la ayuda española, que poco podrían hacer barcos alemanes y franceses fondeados en la bahía si no era admitir a miles de mujeres y niños que corrían a cobijarse en ellas y ponerse a salvo de inminente y seguro bombardeo por parte de los americanos ${ }^{20}$.

Las esperanzas españolas estaban en la llegada de la tercera escuadra: la del almirante Cámara que se había hecho a la mar desde Cádiz rumbo a Filipinas. Pero aquella escuadra no llegaría a Manila por arte y gracia del ministro, del Jedive, Hussein-Oassif, que se opuso terminantemente a que los barcos españoles repostaran combustible en puertos de su jurisdicción, teniendo que regresar desde PortSaid a la península con el desencanto que es de suponer en los defensares de la capital del Archipiélago.

El 5 de agosto desembarcan más expedicionarios norteamericanos en Parañaque y 23 cañones de largo alcance, destinados a operar contra los sectores central y derecho de la línea defensiva de Manila.

Este mismo día el general Augustí entregaba el mando supremo del ejército a don Fermín Jáudenes, tal vez para evitar al primero el dolor de verse obligado a capitular. Porque abandonada toda espranza y escaseando en la plaza sitiada las municiones, medicamentos y subsistencias, todo era cuestión de días. Así lo comprendió Anderson, jefe de las tropas americanas expedicionarias, el cual tuvo que contener al impaciente Aguinaldo que deseaba una operación relámpago y más cuando ya había declarado por una solemne proclama la independencia de Filipinas. El general norteamericano sabía muy bien, lo mismo que sus compañeros W. Merritt y George Dewey, que Manila acabaría por rendirse, como así sucedió. Los españoles hasta el grado heróico, contraatacando valientemente siempre que les fue posible heridos en lo más hondo de su honor potriótico. 'Todo inútil, al amanecer del 13 de agosto, el citado general Anderson desplegó sus dos brigadas frente a los bravos defensores de Manila. Al mismo tiempo, la escuadra del almirante Dewey avanzó desde Cavite dis-

20. El cronista, testigo de los hechos que narra, dedica un elogio al cónsul francés Mr. Berard y al alemán Jr. Krugger, así como al almirante de Ia misma nacionaliaad Von Driederich, que visitaron lá capital dè Mánila durante el asedio y recorrieron la línea de fuego ofreciéndose a prestarles ayuda cuando la necesitaran y que iba a ser bien pronto (Sastrón, 414). 
puesta a cañonear las trincheras españolas a placer y sin que ni un solo barco o cañón enemigo se lo impidiera.

Batidos por el fuego de la escuadra, más que arrollados por el ejército de tierra, los heroicos soldados españoles hacían pagar muy caros los avances del enemigo. Pero en las primeras horas del 14 de agosto todo había terminado: en el Fuerte de Santiago, el general Jáudenes izó bandera blanca y dió órdenes a sus jefes y oficiales de otros fuertes que se dirigiesen al convento de San Agustín para conferenciar sobre la rendición ${ }^{21}$. La capitulación de Manila; nunca vergonzosa, pero sí inevitable y dolorosa, significó para España la puesta de sol de aqual viejo imperio en el que hubo un tiempo no se conocía semejante fenómeno. Era, ni más ni menos, que el desastre colonial de $1898^{22}$.

21. En el Museo Misional de Agustinos Filipinos de Valladolid se conserva la mesa de capitulación, traida desde el convento de San Agustin de Manila, y también la espada del general Jáudenes que entregó - todo un símbolo- a los religiosos Agustinos como recuerdo de aquel trágico día para la historia de España.

22. Manuel Sastrón, que repetidas veces nos dice que fue testigo del asedio de Manila, nos cuenta cómo se le desgarraba el alma al contemplar a aquellos bravos y heroicos soldados españoles, destrozados en el cuerpo y en el espíritu, cómo lloraban al tiempo de arriar la bandera de la Patria del Ayuntamiento de Manila, siendo sustituida por la de Estados Unidos. "Sin faltar gravemente a la obligada molestia - termina Sastrónno debemos decir nosotros si también vertimos algunas de aquellas lágrimas. Lo que sí debemos manifestar... es que, al ver desprenderse de la tierra sagrada de la Patria el gran fragmento de la misma que habiamos venido defendiendo con todas nuestras fuerzas, nos olvidamos de todo el mal sufrido y hasta de los nombres de sus principales aunque inconscientes causantes, para concentrar todos nuestros sentimientos en el patrio amor y expresarles con la única para nosotros consoladora frase: iViva España!". (SASTRoN, o.c. 509). 


\section{c. El Tratado de París}

El tratado de París representa una de las fechas más tristes y a la vez trascendentales de la historia de España. Representa la última etapa de la decadencia española que había comenzado con la crisis del siglo XVII. Representa también la liquidación del imperio secular español.

Los historiadores nos hablan de las humillaciones y vejaciones que sufrieron los plenipotenciarios españoles por parte de los norteamericanos, sin lograr de la engreída nación vencedora ni la más pequeña concesión en lo referente a Filipinas, el reconocimiento de la deuda de Cuba, a la nacionalidad de los nacidos en territorios cedidos, y lo que es más vergonzoso para los vencedores, en lo relativo a la catástrofe del (Maine)"

Aunque no del todo exactas estas apreciaciones - pues hubo acuerdo y cesión por parte de los Estados Unidos en algunos puntos, como luego veremos--, todo lo que nos dicen Ballesteros y otros historiadores resulta aceptable. Ganada la guerra por los Estados Unidos, era natural -y así lo estima Fernández Almagro- que se mostrara exigente con España respecto del futuro de Cuba, Puerto Rico y Filipinas. De tal manera que la disyuntiva en que se encontraba España para obtener una paz honorable era aún más grave que la que hubo de serle planteada en el arranque de la guerra misma, que tantos males le había acarreado ${ }^{2}$.

Antes de comenzar el conflicto, España estaba atenazada con el siguiente dilema: o vender Cuba de una manera vergonzosa a los Estados Unidos, o pelear a la desesperada, pero con honor, por conservarla. Ahora, el dilema se planteaba desde otro punto de vista: o una paz al dictado y a cualquier precio, o una guerra más larga y dura y sin esperanza hasta la extenuación total; de suerte que no cabía opción.

Sagasta y sus hombres de gobierno tenían ante ellos el problema

1. Véase, por ejemplo, A. Ballesteros y BeretTa, "Historia de España $y$ su influencia en la Historia Universal", Ediciones Salvat, (Barcelona 1936) VIII, 433.

2. M. FERnANDez Almagro, "Historia política de la España contemporánea", II. 566 . 
más serio que se había planteado en los últimos añcs. A Cánovas ya no se podía acudir, pues había caído de un modo lamentable mientras descansaba en un balneario. Pero quedaban otros políticos y militares de prestigio y a todos ellos se consultó. Casi todos se inclinaron por la paz como mal menor para España. Y es que "¿quién sería capaz de aconsejar lo contrario - venía a decir Silvela - si a juicio del gobierno se carecía de elementos suficientes para cambiar el curso de la guerra? $)^{3}$.

El único discrepante fue en esta ocasión el independiente Romero Robledo, el cual dijo tajantemente: "Mi opinión es hoy un voto particular, pero mañana podrá ser la de todo el país: y es que siga la contienda, que la haya una vez siquiera. ¿Con qué medios? Con los que le da una nación somo España la conciencia de su derechos" "

Romero Robledo, extraño y pertinaz, necesitaba apoyarse en alguna razón; pero aquí es donde fallaba. Como argumento más convincente alegaba el ejemplo de los españoles de la guerra de la Independencia, los cuales no contaban ni con medios, ni con dineros, y sin embargo, lucharon hasta el final ganando la guerra a Napoleón. Quizá nuestro político, convertido ahora en patriotero, fuera con su argumentación demasiado lejos; y ya sabemos que lo que prueba demasiado, según un aforismo de la filosofía escolástica, no prueba nada, como ocurre en este caso.

No cabía, pues, otra postura que la de la paz y con las condiciones que exigieran los Estados Unidos, por muy doloroso que esto resultara para los españoles y para la gloriosa nación descubridora del Nuevo mundo. Y así, en Consejo de Ministros de I I de agosto de aquel histórico 1898 , cuando todavía no había capitulado Manila, se acordó autorizar al embajador de Francia en Washington, Jules Cambon, para firmar en representación de España, el acuerdo diplomático por el cual el vencido aceptaba las condiciones propuestas por el vencedor. El texto del protocolo se firmó al día siguiente por el Secretario de Estado de Estados Unidos, Willian R. Day, y el citado embajador francés Cambon, este último con plenos poderes del gobierno de España. El texto es de sobra conocido, ha sido insertado

3. Ibid. 567 .

4. Ibid. 568 . 
por cuantos historiadores se han ocupado del asunto y huelga aquí su publicación ".

Cuatro días más tarde, Silvela publicaba en " El Tiempo» el celebre artículo (Sin pulso", que iba a ser como el comienzo de una literatura llamada (del Desastre», y punto de partida de la generación dal $9^{8}$ \%, descubierta, en principio, por el duque de Alba y definida claramente por Azorín en las páginas del A B C.

El jefe del partido liberal aconsejaba entonces lo siguiente: "Hay que dejar la mentira y desposarse con la verdad; hay que abandonar las vanidades y sujetarse a la realidad, reconstituyendo todos los organismos de la vida nacional sobre los cimientos, modestos pero firmes, que nuestros medios nos consienten" ${ }^{6}$.

La Comisión que había de llevar a París la voz de España estaba presidida, por D. Eugenio Montero Ríos. La Comisión americana estaría a su vez, presidida por el citado Secretario Willian R. Day. La papeleta confiada al político y diplomático español, era harto difícil, si bien el pleito podía darse por perdido de antemano, después de la doble capitulación militar y de la firma del Protocolo de Paz. Todo lo demás era hacerse vanas ilusiones. Muy poco había ya que hacer en París ante los soberbios y vencedores diplomáticos norteamericanos. Nada en cuanto a Cuba y Puerto Rico y poco en cuanto a Filipinas, a no ser la aclaración a favor de España de un equívoco léxico disfrazado en la palabra "controle», mucho más exigente en el idioma inglés que en el francés.

Los estados Unidos se obligaban a pagar a España la suma de veinte millones de dólares en los tres meses siguientes al canje de ratificaciones del tratado. Se obligaba también a transportar desde $\mathrm{Ma}$ nila los soldados españoles prisioneros, y a restituirles sus armas. Durante diez años serían admitidas en Filipinas las mercancías y barcos españoles en las mismas condiciones que los yanquis. Los súbditos españoles naturales de España y residentes en territorios cedidos conservarían su religión y podrian durante un año optar por la nacionalidad española. La nacionalidad de los naturales de los citados territorios debía definirla el Congreso de los Estados Unidos de Améri$\mathrm{ca}^{7}$.

5. Puede verse en Fernández Almagro, o. c. 568-69.

6. "El Tiempo", de Madrid, 16 de Agosto de 1898.

7. A. Ballesteros y BeretTA, "Historia de España", VIII, 433-34. 
La Conferencia Hispano-americana inició sus sesiones el día primero de octubre. Son sobradamente conocidas todas las condiciones acordadas en el Tratado de París. Por este Tratado, España renunciaba a la soberanía de Cuba - en realidad, lo único que se hace es la ratificación del Protocolo de Agosto- y cedía Puerto Rico, Guam y Filipinas a los Estados Unidos.

Por lo que se refiere más concretamente a nuestro tema, Estados Unidos exigió la anexión total del Archipiélago filipino, incluso las islas de Joló y Mindanao, que España había tratado de conservar. Los Estados Unidos, una vez más, se mostraron exigentes en exceso. No hubo lugar a concesiones. España sólo pudo refrendar, en el último (memorandum», que sacrificaba sus intereses coloniales en aras de la paz y para evitar la reanudación de una guerra que, evidentemente, no podía sostener con una nación mucho más poderosa que ella ${ }^{8}$.

Por su parte, la Comisión noteamericana reconoció el celoso cuidado, la sabiduría y habilidad, así como la uniforme cortesia con que habían procedido sus antagonistas en la negociación del Tratado»?

Las paces se firmaron el día ro de diciembre, como queda apuntado arriba, de aquel infausto 1898 . El 31 del mismo mes entraban en La Habana las tropas norteamericanas, expectantes en Marianao; y el primer día del año I899 se hizo la transmisión de poderes.

El (desastre», -concluyen los historiadores al unísono-, produjo un verdadero estado de postración nacional. Algún estadista extranjero creyó en la "muerte civil de España), pues desaparecía la influencia de esta nación en el mundo y bien podría pronunciarse el (finis Hispaniae», o fin de España. Los que llegaban entonces a la edad civil, y se conocen hoy con el nombre de "generación del $9^{8}$ "), veían truncados los ideales de su vida y cayeron en un hondo "pesimismo». Buscaban con afán las causas de la catástrofe y coincidían la mayoría en considerar que los directores del país eran los verdaderos culpables. Escritores de más años y prosapia, como Macías Picavea, Joaquín Costa, lanzaron apocalípticas acusaciones y proclamaron remedios heroicos para salvar al pueblo español ${ }^{10}$.

Este sería el final del imperio colonial español -escribe Solde-

8. F. Almagro; loc. cit., 870 .

9. Ibid. 871 .

10. Ballesteros Y Beretta; op. cit., 435. 
vila-; aquel imperio que había comenzado el 30 de agosto de $\mathrm{I}_{282}$, cuando los primeros almogáraves desembarcaban en Sicilia, primer episodio imperial, terminando todo con la venta de las Carolinas y las Marianas, y más que nada con la heroica y titánica defensa del fuerte de Baler, bajo el mando del capitán Enrique de las Morenas y muerto ést:, bajo el mando del teniente Martín Cerezo, el cual, con un puñado de valientes, sostuvo el sitio por más de once meses y cuando hacía ya más de seis que se habían firmado las cláusulas del Tratado de París.

Ante la ejemplaridad de estos héroes, quedaba la esperanza de que un día se cumpliera la profecía del poeta hispano-americano, cantor de una raza, cuando se dirigía al más poderoso de los presidentes del mundo.

“¡Tened cuidado! ¡Vive la América Española! Hay mil cachorros sueltos del León español.

Se necesitaría, Rooselvelt, ser Dios mismo

el Rifero terrible y fuerte Cazador, para poder tenernos en vuestras férreas garras.

$\mathrm{Y}$, pues, contáis con todo, falta una cosa: ¡DIOS! ${ }^{11}$

11. Ruben Dario: "Cantos de vida y esperanza", Poesia "A Rooselvelt" Ediciones Anaya (Madrid 1964), 34. 